\title{
The Implications of Deregulation for Biomass and Renewable Energy in California: Revision
}

Gregory Morris

Future Resources Associates, Inc.

Berkeley, California

Technical Monitor: R.P. Overend

DISTRIBUTON OF THIS DOCUMENT IS UNLIMITED

\section{MASTER}

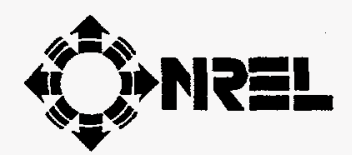

National Renewable Energy Laboratory 1617 Cole Boulevard

Golden, Colorado 80401-3393

A national laboratory of the U.S. Department of Energy Operated by Midwest Research Institute for the U.S. Department of Energy

Under Contract No. DE-AC36-83CH10093

Prepared under Subcontract Number AXE-7-17024

Revised August 1998 
This publication was reproduced from the best available camera-teady copy submitted by the subcontractor and received no editorial review at NREL.

\section{NOTICE}

This report was prepared as an account of work sponsored by an agency of the United States govemment. Neither the United States government nor any agency thereof, nor any of their employees, makes any warranty, express or implied, or assumes any legal liability or responsibility for the accuracy, completeness, or usefulness of any information, apparatus, product, or process disclosed, or represents that its use would not infringe privately owned rights. Reference herein to any specific commercial product, process, or service by trade name, trademark, manufacturer, or otherwise does not necessarily constitute or imply its endorsement, recommendation, or favoring by the United States govemment or any agency thereof. The views and opinions of authors expressed herein do not necessarily state or reflect those of the United States government or any agency thereof.

Available to DOE and DOE contractors from:

Office of Scientific and Technical Information (OSTI)

P.O. Box 62

Oak Ridge, TN 37831

Prices available by calling (423) 576-8401

Available to the public from:

National Technical Information Service (NTIS)

U.S. Department of Commerce

5285 Port Royal Road

Springfield, VA 22161

(703) $487-4650$ 


\section{DISCLAIMER}

Portions of this document may be illegible electronic image products. Images are produced from the best available original document. 


\section{Executive Summary}

Since its inception more than 100 years ago, the electric utility industry has been considered a natural monopoly, requiring either public ownership or regulation to ensure fairness in the marketplace. Electricity generation is the most capital-intensive industry in the economy, and presents a significant barrier to market entry. Local distribution facilities are a major part of basic municipal infrastructure, and duplication would be highly undesirable. Moreover, to be usable, electricity must conform to rigid specifications (voltage, cycles), making product differentiation unusually difficult. Thus, electric utilities have traditionally been assigned exclusive franchise areas, with public oversight substituted for market competition.

In the interest of promoting economic efficiency and consumer choice, all that is about to change. $\mathrm{AB}$ 1890, California's landmark electric utility deregulation legislation, was signed into law in September 1996. $\mathrm{AB} 1890$ set January 1,1998 , as the date on which the restructuring of the electric utility industry would begin. This meant that the many facets of implementation had to be completed during a 15-month period, a daunting challenge.

A potential deficiency of unfettered market competition acknowledged in $\mathrm{AB} 1890$ is that environmentalquality concerns are not addressed by natural market forces. Energy production is one of society's major sources of air pollution and greenhouse gas emissions. Some of the cheapest energy sources, such as coal, are among the most highly polluting. To address this problem, $A B 1890$ provides for the creation of a renewables transition fund, to be collected and invested during a 4-year transition period, to promote the future competitiveness of renewables within the context of a fully restructured market. AB 1890 also recognizes the special waste-disposal services provided by biomass power generation, and envisions the enactment of policies to shift some of its costs to the beneficiaries to promote its long-term viability.

AB 1890 assigned to the California Energy Commission (CEC) the task of proposing a comprehensive plan for allocating the renewables transition funds, which would total $\$ 540$ million over the 4-year transition period to the full implementation of market restructuring. The legislation stipulates that at least $40 \%$ of the funds be used to support existing renewable generators, and at least $40 \%$ of the funds be used to support new and emerging renewables. The CEC was given 6 months to formulate a detailed plan for the use of the funds, and report back to the legislature. AB 1890 assigned to the California Environmental Protection Agency (Cal/EPA) the task of reporting on the special benefits of biomass power generation, and formulating a plan for the development of cost-shifting policies that would support the biomass industry after the transition period. Like the CEC, Cal/EPA was given 6 months to report back to the legislature.

The CEC convened a series of public hearings and workshops to elicit proposals from interested parties for the allocation of the renewables transition funds. More than a dozen proposals were submitted, five of which provided comprehensive programs for the use of the funds. The proposals represented a broad spectrum of approaches and priorities. The major issues of contention included:

- How much of the $20 \%$ of the funds not allocated by the legislation between existing, and new and emerging, should go to each category. 


\section{The Implications of Deregulation for Biomass and Renewable Energy in California}

- Whether and how funds should be allocated among the various renewable technologies within the categories of existing, and new and emerging, systems.

- How to allocate between new conventional renewables technologies, and new emerging renewables technologies.

- Whether the funds would be better spent on directly supporting renewables generators, or on providing support to renewables marketers and purchasers.

The CEC renewables committee deliberated over the proposals and issues, and formulated a comprehensive plan that contained many features of consensus that had emerged from the process, and reflected the judgment of the agency. The final CEC report was submitted to the legislature on schedule. It proposed the allocation of $45 \%$ of the funds to existing generators, $30 \%$ to new generators, $10 \%$ to emerging generators, and $15 \%$ for customer rebates for qualifying green power sales. Funds for the existing sources were further divided into three technology-specific tiers, in recognition of the differential needs of the technologies. Funds for new and emerging technologies, and for customer rebates, promote full competition among the eligible renewable generating sources. The legislature accepted the report, and implemented it through the enactment of SB 90 during the 1997 legislative session.

$\mathrm{Cal} / \mathrm{EPA}$ includes two agencies with a major interest in the future of the biomass power industry in California: the California Integrated Waste Management Board (CIWMB), and the California Air Resources Board (CARB). Cal/EPA assigned primary responsibility for the biomass cost shifting study to the CIWMB, which convened a series of public workshops to explore issues, consider studies that have analyzed the value of the waste disposal benefits associated with biomass power generation, and receive proposals for cost-shifting measures that could promote the competitiveness of biomass power generation in California. The existing biomass power industry, as well as a number of interested parties, made proposals for cost-shifting measures to the CIWMB, which were presented and discussed at the workshops.

At the close of the public workshop process, the CIWMB produced a draft report to the legislature on the value of the biomass power industry, and cost-shifting measures to promote its viability. This draft report was circulated to parties of record in the workshop process, as well as to the public. At the same time, CARB produced its own report on the air quality implications of biomass power generation, which was done without public input or comment. The CARB report was less supportive of the conclusion that biomass power generation provides air quality benefits than any of the other parties to the CIWMB workshop process had been, and failed to endorse a strong role for biomass power generation in mitigating the impacts of the open burning of agricultural residues in the state. The CARB report, which was released just days before to the due date for the Cal/EPA report, threw the agency into a quandary. Its solution was to issue a vastly scaled-back report that failed to take a strong stand on the development of cost shifting measures for the state's biomass power industry. The report did incorporate, as an appendix, the executive summary of the Future Resources Associates, Inc., report to NREL: The Environmental Costs and Benefits of Biomass Energy Use in California, 1997.

The immediate future of biomass power production in California is secure. The renewables transition funds that are being managed by the CEC provide support for the industry throughout the course of the transition period to full deregulation, which ends on December 31, 2001. However, after the close of the transition period, the future of biomass power generation will be very uncertain. The report from $\mathrm{Cal} / \mathrm{EPA}$ to the California legislature did not provide the information needed to proceed with the development of post-transition cost-shifting policies, so no further action has been taken. The legislature 
is on record as favoring the development of such policies, in which a clear public benefit can be demonstrated. The task at hand is to develop such a framework, and to formulate policies and measures that will allow biomass power production to be a competitive enterprise, without shifting undue costs to the beneficiaries of the environmental services provided by biomass energy generation. Failure to enact cost-shifting measures probably will lead to a major decline in the production of biomass energy, with attendant degradation of air quality and forestry health, and increasing difficulty in meeting state landfill diversion requirements. A great deal is at stake. 


\section{Table of Contents}

Executive Summary

Table of Contents

iv

Lists of Tables, Figures, Appendices

Lexicon

vii

Introduction

Allocation of Renewables Transition Funds ..................................................................

CEC Hearing Process .......................................................................................... 2

Proposals for the Allocation of Transition Funds.......................................................... 2

Issues in Allocating Renewables Transition Funds................................................... 5

Definitions of Renewables ...................................................................................... 6

Cost Effectiveness of Renewables—Need for Transition Support ...................... 7

Solid-Fuel Biomass ....................................................................................... 7

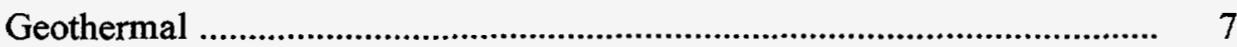

Solar Thermal (Luz) ........................................................................ 8

Wind.......................................................................................... 8

Landfill Gas, MSW, Tire-Derived Fuel, Small Hydro................................ 9

Market Mechanisms and Application of the Transition Funds ........................... 9

Existing Versus Emerging Technologies ........................................................ 14

CEC Report to the Legislature ........................................................................ 12

Cost-Shifting Measures for Biomass Energy Production ................................................. 13

The Need for Cost Shifting for Biomass Energy........................................................ 13

Revenues Paid to Power Producers for Electricity and Capacity Sales ............... 13

Type of Biomass Fuel Used ............................................................................ 14

Size of the Overall Biomass Fuels Market in the State....................................... 16

New Versus Existing Biomass Generating Facilities........................................ 17

Cost-Shifting Requirements ................................................................... 17

CIWMB Hearing Process..................................................................................... 18

Cost-Shifting Measures Proposed to the CIWMB ................................................... 19

Cost-Shifting Measures Applicable to All Biomass Fuels ................................... 19

Renewable Energy Tax Credit ........................................................... 20

Diesel Fuel Tax Rebate ....................................................................... 20 
Minimum Purchase Requirement........................................................... 20

Cost-Shifting Measures Applicable to Landfill-Diverted Biomass Fuels............. 21

Waste Diversion Credit........................................................................ 21

Tipping Fee Surcharge .......................................................................... 21

Cost-Shifting Measures Applicable to Agricultural Biomass Fuels .................... 22

Agricultural Fuels Tax Credit .................................................................. 22

Open Burning Permit Fees........................................................................ 22

Open Burning Reduction Credits ............................................................... 22

Cost-Shifting Measures Applicable to In-Forest Biomass Fuels ........................ 23

Wildfire Prevention Credits ...................................................................... 23

Water Production Credits....................................................................... 23

The Cal/EPA Report to the California Legislature...................................................... 24

A Proposed Implementation Strategy for Biomass Cost Shifting in California............ 25

Targeted Cost Shifting Options ...................................................................................... 26

Urban Wood Residues..................................................................................... 27

Problem ......................................................................................... 27

Cost-Shifting Strategies ...................................................................... 27

Discussion ........................................................................................... 27

Agricultural Residues............................................................................. 28

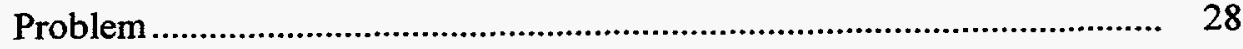

Cost-Shifting Strategies ..................................................................... 28

Discussion ....................................................................................... 28

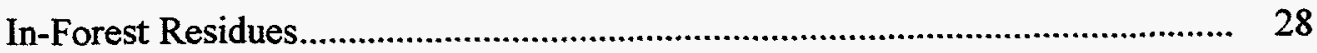

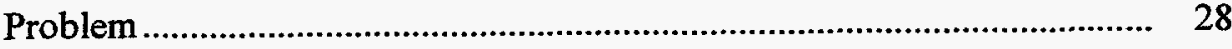

Cost-Shifting Strategies .................................................................... 29

Discussion ..................................................................................... 29

Future Prospects for Biomass and Renewable Energy Production in California ................. 30

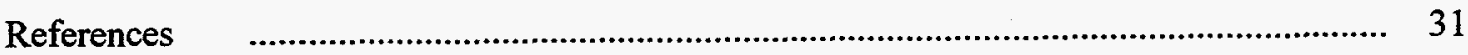


The Implications of Deregulation for Biomass and Renewable Energy in California

\section{List of Tables}

Table 1: $\quad$ Comprehensive Proposals to the CEC Renewables Program Committee

Table 2: $\quad$ Features of Proposals to the CEC Renewables Program Committee

Table 3: $\quad$ California Avoided Cost Rates, Historical and LCG Projections

Table 4: $\quad$ California Time-Differentiated SRAC Rates, 1997

Table 5: $\quad$ Characteristics of Biomass Fuels Used in California

Table 6: $\quad$ Cost Shifting Needs for Biomass Power Production

Table 7: Average Cost of Biomass Fuel Production in California

Table 8: $\quad$ Schedule of CIWMB Workshops on Biomass Cost Shifting Strategies

\section{List of Figures}

Figure 1: $\quad$ Short Run Avoided Costs in California, $1980-1997$

Figure 2: $\quad$ California Biomass Fuels Market by Category

Figure 3: $\quad$ California Biomass Fuel Supply Curve

\section{Appendices}

Appendix 1: Full Text of AB 1890, Article 7, Section 383

Appendix 2: Schedule of CEC Hearings and Workshops, Renewables Program Committee 


\section{The Implications of Deregulation for Biomass and Renewable Energy in California}

\section{Lexicon}

AB 939: California's solid waste recycling legislation, passed in 1990.

AB 1890: California's electric utility restructuring legislation, passed in 1996.

SB 90: California legislation establishing the renewables and public interest transition programs, passed in 1997. This legislation follows up on $A B 1890$.

EPACT: Energy Policy Act of 1992, federal legislation that included tax credits for some renewables.

$\S 45:$ IRS Code Section 45 , Electricity produced from certain renewable resources, the federal renewable energy tax credit created by EPACT.

HR 655 (the Schaefer Bill): Proposed federal legislation for electric utility restructuring, which includes a minimum purchase requirement for renewables.

AQMD: Air Quality Management District, the local air quality regulatory agencies in California. $A Q M D s$ were the lead agencies for permitting most biomass facilities in the state.

AWEA: American Wind Energy Association, an industry organization.

bdt: Bone dry ton, a unit of measurement for biomass fuels that refers to the dry weight content of the material, which is the part that provides energy.

Cal/EPA: California Environmental Protection Agency, which includes all the major health and environmental state agencies. Cal/EPA was assigned the task of reporting to the state legislature on costshifting strategies for biomass energy generation.

CARB: California Air Resources Board, which operates under the umbrella of the Cal/EPA.

CBEA: California Biomass Energy Alliance, an industry organization.

CDWR: California Department of Water Resources, which operates under the umbrella of the Cal/EPA.

CIWMB: California Integrated Waste Management Board, which operates under the umbrella of the $\mathrm{Cal} / \mathrm{EPA}$.

CDFFP: California Department of Forestry and Fire Prevention.

CEC: California Energy Commission, the state agency that is administering the renewables transition program created by $\mathrm{AB} 1890$.

CPUC: California Public Utilities Commission, the state agency that regulates the investor-owned electric utility companies in California.

FRA: Future Resources Associates, the firm that performed this study. 
The Implications of Deregulation for Biomass and Renewable Energy in California

Luz: Luz engineering, the company that developed $350 \mathrm{MW}$ of solar trough generating facilities in the southern California deserts. The technology is often referred to as Luz.

MSW: Municipal solid waste, mixed garbage.

NREL: National Renewable Energy Laboratory, the sponsor of this study.

O\&M: Operations and maintenance, the annual operating cost for generating electricity.

PG\&E: Pacific Gas \& Electric Co., a regulated, investor-owned utility company in northern California.

PPA: Power Purchase Agreement, a contract to sell power to a utility company.

SCE: Southern California Edison Co., a regulated, investor-owned utility company in southern California.

SO\#4: Interim Standard Offer No. Four power purchase contracts that were available to developers during the period 1984-1985, and which formed the basis for the development of the renewables energy industries in California. SO\#4s provided for long-term levelized capacity payments, and fixed energy payments for the first 10 -years of operations.

SRAC: Short-Run Avoided Cost, the price paid to non-utility power generators in California that are not receiving fixed energy payments. SRAC currently is set monthly. 


\section{The Implications of Deregulation for Biomass and Renewable Energy in California}

\section{Introduction}

California has been leading the nation down the path of electric utility deregulation, beginning with the April 1994, California Public Utilities Commission's (CPUC) Blue Book restructuring proposal. The road for renewable energy producers has been particularly rocky, leaving the future of renewable energy production very much in doubt. The original CPUC proposal provided for competition among generating sources on the basis of price alone, without regard for environmental considerations.

The California legislature took up electric utility deregulation legislation during 1996, culminating in $A B$ 1890 , California's landmark restructuring legislation, which was passed unanimously by the Senate and Assembly, and signed into law by the governor on September 28, 1996. The legislation created a transition funding program for renewables for the f4-year phase-in scheduled for the restructuring program, to be financed by a lines surcharge collected by the utility companies in parallel with their collection of funds for stranded cost recovery. No permanent program for the support of renewable energy production extending beyond the end of the transition period (2002) is included in $A B 1890$.

$\mathrm{AB} 1890$ assigned to the California Energy Commission (CEC) the task of determining how to allocate the renewables transition funds between existing and new renewable generating sources, and among the various renewable energy technologies that are available for deployment in California. The California Environmental Protection Agency (Cal/EPA) was assigned the task of reporting to the legislature about the specific benefits provided by biomass energy production in California, and about policies that could shift some of the cost of biomass energy production away from the electric ratepayer, on to beneficiaries of the environmental benefits of biomass energy production.

This study describes the development of the CEC and Cal/EPA reports to the California legislature, and provides an analysis of the major issues that were encountered during the course of their development. The study concludes with a consideration of the future prospects for biomass and renewable energy production in the state.

\section{Allocation of Renewables Transition Funds}

Article 7 of $\mathrm{AB} 1890$ provides for a fund of as much as $\$ 540$ million to be collected from electric ratepayers on behalf of renewable energy sources, to help renewable energy production make the transition from the current regulated electricity market to the competitive market of the future. The funds will be collected by the existing regulated electric utility companies in the state as a non-bypassable surcharge, in much the same way that the utilities will charge customers for the recovery of their stranded costs. The legislation directed the CEC to report to the legislature by March 31, 1997, with a proposal for allocating the renewables transition funds, to achieve the objectives of the restructuring legislation.

These transition funds are to be collected and spent during the 4-year period specified in the legislation for the transition from the current regulated market, to the restructured, competitive market of the future. 


\section{The Implications of Deregulation for Biomass and Renewable Energy in California}

The transition period begins on January 1, 1998, and lasts exactly 4-years, by which time restructuring will be fully deployed.

$\mathrm{AB} 1890$ 's objectives with respect to the renewables transition funds are articulated in Section 383 of the legislation, summarized as follows (the full text of Section 383 is included as Appendix 1 to this report):

- Support the operation of existing renewables, and the development of new and emerging renewable generating facilities.

- Support the operations of biomass generators because of the environmental services they deliver in suppressing forest fires, reducing landfill and reducing open burning of agricultural wastes.

- Support the operations of solar thermal technologies because of their peak power generation benefits.

- Use market-based mechanisms that reward the most cost-effective renewable generation operations.

\section{CEC Hearing Process}

To comply with its obligation to report to the legislature with recommendations for the allocation of the renewables transition funds, the CEC formed a renewables program committee consisting of Commissioner Michal Moore, presiding member, and Commissioner Jananne Sharpless, second member, and convened a series of public hearings in late 1996 to elicit public participation in the formulation of an allocation program. Interested parties were invited to submit allocation plans to the committee, which were then opened to scrutiny by all participants. Appendix 2 presents a list of the hearing and workshop dates, and includes the CEC's initial notice of workshops and issues.

From the outset, the commissioners made clear that, even though they were ultimately responsible for the report that would be submitted to the legislature, they would prefer to have participants in the process reach consensus positions to the maximum extent possible, so that their proposals would have broad public support. Regardless of the outcome of the process, however, the commissioners made clear that they intended to advocate vigorously for their proposals, once they became crystallized and formalized in their report to the legislature.

At the completion of the series of public hearings, the renewables program committee held a series of private workshops at which the commissioners, their advisors, commission staff, and committee consultants, came together to hammer out a coherent, integrated policy for allocating the transition funds. This process culminated in the issuance of a draft report, following which public hearings were reconvened to allow public comment on the drafts. The report went through a couple of rounds of revision, then a final, full commission hearing was held, and the full commission formally approved the report for submission to the legislature. The report was submitted to the legislature on time, and was received formally at a hearing of the Senate Energy Committee on April 8, 1997.

\section{Proposals for the Allocation of Transition Funds}

The CEC's renewables program committee received more than a dozen proposals for the allocation of the renewables transition funds provided for in $\mathrm{AB}$ 1890, of which five can be considered comprehensive for 


\section{The Implications of Deregulation for Biomass and Renewable Energy in California}

the allocation of the total amount of funds available. The rest tended to be special purpose proposals dealing with individual technologies or limited scope issues.

Each of the five comprehensive proposals was developed and submitted by coalitions of participating parties. These coalitions are summarized in Table 1. Two proposals were developed by groups of renewables generators, one of which was composed of mainly existing generators, and one of which was composed of developers and advocates of emerging renewable technologies. One proposal was developed by a group of green energy services providers, one by a group of environmental organizations, and one by a group of municipalities and landfill gas producers.

Each of the five comprehensive proposals took its own approach to the major allocation issues for the renewables transition funds. The basic allocation issue involves how to distribute the funds between the two primary categories of renewables generators mentioned in $\mathrm{AB}$ 1890. The two primary renewables categories are:

- Existing Renewable Energy Generation Facilities

- New and Emerging Renewable Energy Generation Facilities

The legislation specifies that at least $40 \%$ of the funds are to be allocated to the existing category, and $40 \%$ to the new and emerging categories, and $20 \%$ subject to the recommendations of the CEC. The proposals differed greatly with respect to how to allocate the discretionary $20 \%$ of the funds, to whom to provide incentives (e.g., renewables generators versus green energy services providers or customers), how to allocate between new and emerging technologies within the new and emerging category, and among the various renewable generating sources (biomass, small hydro, geothermal, solar, and wind) within each category.

Two philosophical issues proved to be major points of contention:

- Would the funds be better spent directly supporting specific renewable generating sources, or by providing customer incentives to engender the creation of a green power market?

- Would the funds be better spent on supporting mainly commercial renewable energy technologies, or should a substantial portion of the funds be allocated to the development of the next generation of renewable generating technologies?

In addition, there was a good deal of controversy regarding whether and how two particular renewable energy technologies, small hydro, and landfill gas, should receive support from the renewables transition funds. There appeared to be little question about the needs for and qualifications of solid fuels biomass, geothermal, solar, and wind, for the designated renewables transition funds.

Table 2 summarizes the positions of the comprehensive allocation proposals on the major allocation issues that had to be decided on by the committee. The proposal from the existing technologies coalition was put together by representatives of the organizations representing the four major renewable generating sources used in the state: solid-fuels biomass, geothermal, solar thermal, and wind. The parties attempted to define their own needs, both in total, and divided between existing and new generating facilities. Then, the four groups negotiated a proportional division of the funds among themselves that conformed with the $\$ 540$ million specified in $\mathrm{AB} 1890$. 


\section{The Implications of Deregulation for Biomass and Renewable Energy in California}

The biomass industry determined that there is virtually no chance of new biomass power development in the state during the designated transition period, and that the existing facilities needed all of the help that would be available for biomass. Eligible existing biomass facilities included those that have had their power purchase agreements (PPAs) bought out by the utility companies and shut down operations, and those that are currently operating, but not receiving revenues based on the fixed-price schedule of the standard offer power contracts. Facilities receiving fixed-price schedule payments would not be eligible for assistance from the renewables transition funds.

The geothermal industry expressed the belief that most of their existing, operating facilities will be competitive in the coming restructured market, and that their industry would be best served by applying the bulk of the transition funds earmarked for geothermal to new project development. The industry has identified a couple of potential resource areas that are considered to be prime for development. A small portion of the funds available to geothermal were allocated to existing generators that are old, small, and have high electricity production costs relative to the industry average. These facilities probably will require some assistance to continue operating during the transition period to full competition.

The existing solar-thermal industry consists mainly of the parabolic-trough systems developed by the now defunct Luz corporation. These generators have been split into three ownership groups. There is no expectation of any new development of this technology in the foreseeable future, so the industry proposed allocating all the funds available for their technology to be dedicated to capital improvements to the existing facilities, including possibly some capital buy-downs.

The wind industry proposed a flat incentive payment to all wind-produced electrical output generated during each defined time period, with a cap of $\$ 0.01 \mathrm{kWh}$ on the incentive payment. This would allow each facility owner to determine whether to improve the existing operation, or to invest in a retrofit or repower. In concurrence with federal tax code, retrofits and re-powers in which at least $80 \%$ of the book value of the facility is represented by the new equipment is classified as new. Many of the early wind generators installed in the state have operations and maintenance (O\&M) costs in the neighborhood of $\$ 0.04 / \mathrm{kWh}$, higher than the expected revenue these generators will receive. If these generators are replaced with new equipment, their O\&M costs can be reduced to the range of $\$ 0.01-\$ 0.015 / \mathrm{kWh}$; at the same time, their output can be increased as much as $50 \%$ for a given installed generating capacity. Retrofits and re-powers would allow the early wind energy installations to remain competitive into the foreseeable future. The American Wind Energy Association (AWEA) estimated that approximately 40\% of the wind production incentives would go to existing generators, and $60 \%$ would be paid to generators in the new category, meaning mainly retrofits and re-powers.

The proposal submitted by the emerging technologies coalition would allocate $25 \%$ of the renewables transition funds to emerging technologies, specifically photovoltaics, power tower, and dish-stirling technologies. According to the proponents, this would be enough to materially speed up the commercialization process for these technologies, allowing them to achieve a position of competitiveness by the end of the 4-year transition period. On the other hand, this would severely limit the funds that would be available for the development of new renewable generation facilities based on already commercial technology, as was proposed by the existing technologies coalition. The emerging technologies coalition proposal provides for full competition among all technologies for funds in the existing and new generator categories.

The proposal submitted by the green power providers took a totally different approach to the use of the renewables transition funds. Instead of using the bulk of the funds to provide incentives directly to the producers of renewable power, the green power marketers proposed using the funds to provide customer incentives to encourage the development of a market for green energy. By receiving credits of as much as 


\section{The Implications of Deregulation for Biomass and Renewable Energy in California}

$\$ 0.015 / \mathrm{kWh}$ for green electricity, the green marketers would be able to pay a premium for renewable energy purchases, which would feed back to the producers. However, a major difference between this proposal and the proposals submitted by others is that no facilities selling renewable electricity under PPAs would be eligible to participate in the program. The proposal includes a provision for the creation of realistic exit mechanisms from the standard offer contracts.

The proposal submitted by the coalition of environmental organizations is something of an amalgam of the proposals submitted by the other coalitions. The major compromise offered between the existing and the emerging technologies proposals is the suggestion for an intermediate allocation to emerging technologies of $13 \%$. The balance of the funds are reallocated among existing and new systems, with customer rebates to be used for at least $50 \%$ of the funds allocated to new systems. This proposal supports the concept of directing funds to specific technologies, particularly for the existing generator category, and supports the inclusion of small hydro and landfill gas generators for eligibility for the funds for new systems.

The proposal submitted by the landfill gas coalition differed from the others mainly by establishing landfill gas as an eligible technology for the renewables transition funds. This proposal took the approach that the state's renewables transition efforts should be directed, to the maximum extent possible, toward the development of new generating sources, including landfill gas and biogas generators. In all categories, the landfill gas coalition proposal favors full competition among all renewables.

\section{Issues in Allocating Renewables Transition Funds}

From the outset of the process of developing the CEC report, by all parties recognized that the available funds, $\$ 540$ million to be made available over a 4-year period, would not be sufficient to do all the things everybody wanted to do. Difficult choices would have to be made. AB 1890 contains language that sets forth goals for the use of the funds, but the language is very general. The CEC was given responsibility for making the difficult decisions.

The CEC committee made clear that it would proceed on the assumption that the renewables transition funds specified in $\mathrm{AB} 1890$ would be the only public assistance made available to renewables, with the understanding that renewables would have to stand on their own after the transition period, within the context of the competitive marketplace. Biomass was the one possible exception to this rule. However, the long-term support that might be developed for biomass was not expected to come from surcharge funds. Long-term biomass support came under the heading of cost-shifting strategies, the responsibility for which was assigned to the Cal/EPA by the legislation. Biomass cost-shifting strategies are discussed later in this report.

Based on the CEC committee's approach, one guiding principle that would be applied in the allocation of the renewables transition funds would clearly be that each application of the funds should facilitate a transition for the recipient project to a state of competitiveness at the end of the defined support period. In other words, a subsidy stream during the transition period that left the recipient no better able to compete at the end of the period than at the beginning would be considered to have been spent in vain. In this context, each applicant was expected to provide a rationale for how the funds would produce a readiness for competition at the end of the transition period.

The following discussion considers four major issues that had to be considered in the formulation of an allocation scheme for the California renewables transition funds. The issues are: 


\section{The Implications of Deregulation for Biomass and Renewable Energy in California}

- Definitions of Renewables

- Cost Effectiveness of Renewables

- Market Mechanisms and Application of Funds

- Existing versus Emerging Technologies

\section{Definitions of Renewables}

There appears to be general agreement about whether some energy sources, such as wind and solar, are renewable, but for several energy sources, such as tires, municipal solid wastes (MSW), landfill gas, and petroleum coke, there is some controversy. A primary criterion for eligibility for the renewables transition funds is that the recipient generating source be classified as renewable. California state code does not define renewable energy sources explicitly. AB 1890 defines renewables by exclusion, stating:

Renewable resource technologies [are] defined as electricity produced from other than a conventional power source.

California Public Utilities Code defines conventional power sources as nuclear, fossil fuel, and hydro facilities larger than $30 \mathrm{MW}$. The language of $\mathrm{AB} 1890$ allows every other generating technology to qualify as renewable. Petroleum coke, although a waste product, would probably be excluded as a fossil fuel, but tires, MSW, and landfill gas would all appear to qualify as renewables. Tires and MSW both contain components that are petroleum derivatives, but both also contain substantial quantities of biomass (natural rubber from radial tires, paper in MSW), both are post-consumer wastes, and neither is properly classified as a fossil fuel.

At the federal level, there is an inconsistent classification of what constitutes renewable generating sources. The Federal Power Act, in defining qualifications for a "small power production facility," does not differentiate between biomass and waste resources as renewable fuels. The Energy Policy Act of 1992 (EPACT), however, distinguishes between MSW and biomass. In Section 1212, which defines eligibility for the Renewable Energy Production Incentive, a qualified renewable energy facility can use: "solar, wind, biomass, or geothermal energy, except that the burning of municipal solid waste shall not be treated as using biomass energy."

The exclusion of MSW as a renewable generating option is also included in the current version of the Schaefer restructuring bill, which is still being crafted for consideration in the coming federal legislative session. MSW as a renewable generating source has been excluded not for any philosophical principle regarding its renewability. A number of environmental organizations believe that MSW combustion is not the most desirable option for waste disposal, MSW from the definition of biomass was excluded as a compromise measure. Tire-derived fuels are not addressed explicitly in EPACT or Schaefer.

U.S. tax code defines biomass property as equipment that uses an "alternate substance" as fuel, which means that it is not coal, oil, or natural gas, nor any product of coal, oil, or natural gas. This could be interpreted in such a way as to place tire-derived fuels in a gray area, because many tires contain substantial quantities of synthetic rubber, a petroleum product. On the other hand, much of the rubber in tires is actually made from biomass (natural rubber). Radial tires, for example, are mostly natural rubber, because natural rubber is stronger than synthetic rubber. A minimum percentage content of natural rubber is required for radial tires. On the basis of the federal tax code, MSW and landfill gas would apparently would qualify as renewable fuels for purposes of qualifying for depreciation treatment as biomass property, and tire-derived fuels probably would qualify as renewables, although a case could be made against their qualification. 
The Implications of Deregulation for Biomass and Renewable Energy in California

\author{
Cost Effectiveness of Renewables-Needs for Transition Support
}

Solid-Fuel Biomass

The generic cost of power generation from biomass solid fuels $(\$ / \mathrm{kWh})$ has been estimated as follows:

\title{
Cost of Biomass Fuel Production $(\mathbf{\$} / \mathbf{k W h})$
}

$\begin{array}{lll} & \underline{\text { FRA }} & \text { CBEA } \\ \text { Non-Fuel O\&M } & 0.0250 & 0.0225 \\ \text { Fuel } & 0.0250 & 0.0250 \\ \text { Capital \& Related * } & \underline{0.0200} & \underline{0.0225} \\ \quad \text { Total } & 0.0675 & 0.0700 \\ \quad \text { Total, zero fuel cost } & 0.0450 & 0.0450\end{array}$

FRA: Morris, Gregory, The Environmental Costs and Benefits of Biomass Energy Use in California, NREL Report No. NREL/SR-430-22765, May 1997.

CBEA: unpublished work by the California Biomass Energy Alliance, submitted to the CEC renewables docket.

- This is an estimate for the existing, partially amortized facilities in California.

In order to allow the existing facilities to be operated sustainably in the future competitive market for power generation, they will probably need to be compensated somehow, for their waste disposal and treatment services. This is the focus of the development of cost-shifting strategies, which are considered later in this report. If the biomass fuel cost can be zeroed out from the electricity production balance sheet, generating cost drops from the present level of approximately $\$ 0.0675-\$ 0.0700 / \mathrm{kWh}$ to $\$ 0.045 / \mathrm{kWh}$. This is a level at which the facilities could operate sustainably in the future, with energy sales at what are expected to be competitive market prices of approximately $\$ 0.030 / \mathrm{kWh}$, plus long-term firm capacity sales of approximately $0.015-0.020 / \mathrm{kWh}$.

Biomass conversion to electricity provides ongoing waste disposal and treatment services to the state, and the continuing provision of these services probably will require ongoing support in the form of costshifting policies that are tied to these environmental services. The needs of biomass generating sources are not just a matter of transition support until there is a competitive marketplace, when all support can end. Support of approximately $\$ 0.020-0.025 / \mathrm{kWh}$, either in the form of a reduction in fuel cost, or through some other means, appears to be necessary for long-term sustainability of biomass power generation. The transition funds can be used as a bridge to the implementation of permanent cost-shifting policies.

\section{Geothermal}

Geothermal power production in efficient, existing generating facilities appears to be competitive with conventional generating sources. The industry claims this to be the case. A few of the oldest, smallest, and least efficient of the state's operating geothermal generating facilities have operating costs that may make them non-competitive in the future market, but for the most part, this is one renewable generating 


\section{The Implications of Deregulation for Biomass and Renewable Energy in California}

source whose existing fleet of facilities will not be adversely affected by having to compete in the deregulated market for electricity generation.

The geothermal industry's major request to the CEC renewables committee for support from the AB 1890 funds was in the area of capital cost buy-downs for new generating facilities. There are a couple of promising resource regions in the state that the major geothermal developers would like to develop. The facilities they would build would have operating costs that are competitive with conventional generating sources, so that the major barrier to their development is the capital cost hurdle.

\section{$\underline{\text { Solar Thermal (Luz) }}$}

Like biomass, solar thermal power generation was identified in $\mathrm{AB} 1890$ as an especially desirable source of renewable power generation. Its role as a reliable provider of peak power to the utility grid is mentioned specifically in the legislation. This strength is also reflected in the standard offer PPAs under which these facilities sell power to SCE. At the completion of the fixed-price periods in their contracts, the major source of revenue for the Luz generators in southern California is capacity revenue, which is strongly skewed toward peak power sales.

The Luz systems, which began operations in the late 1980s, earn capacity revenues on the basis of contract capacity prices in the range of $\$ 160-\$ 200 / \mathrm{kW}$-yr. For a base-load facility with constant output this averages about $\$ 0.02 .0 / \mathrm{kWh}$ capacity revenues in addition to energy sales revenues. However, for a facility operating with the output profile of a Luz-type generator, the average capacity revenue is more than $\$ 0.047 / \mathrm{kWh}$ generated. Thus if the future market price for power averages $\$ 0.03 / \mathrm{kWh}$, then the Luz facilities will be earning $\$ 0.077 / \mathrm{kWh}$ on average for their power sales, under their existing PPAs, and the industry will have to be able to perform against this standard to operate sustainably in the future.

The Luz systems were pioneering installations, and much has been learned through the course of their development. The existing facilities currently are owned and operated by three distinct companies, which cooperate on matters of facility upgrades and O\&M practices. These companies proposed to use the transition funds available for solar thermal power generation for capital improvements and capital cost buy-downs, which would allow them to achieve competitiveness in the future market, given their firm capacity PPAs. There is no expectation that any new solar thermal power generating capacity will be developed in the state in the foreseeable future.

\section{Wind}

Modern, state-of-the-art wind turbines have capital costs in the range of $\$ 1,000-1,100 / \mathrm{kW}$ of capacity, and can achieve capacity factors of approximately $27 \%-30 \%$ under typical California wind regime conditions. These turbines have projected O\&M costs of $\$ 0.075-\$ 0.125 / \mathrm{kWh}$, so they clearly can be competitive in the future restructured market if the cost of their installation can be substantially amortized during the transition period.

Many of the old, early-technology, existing wind machines operating in California have much higher operating costs, and cannot even compete in the existing, pre-restructured market. The proof of this is that wind electricity production has been declining over the past several years, with many machines simply shut down when repairs are required, often to be used as a source of spare parts.

Re-powering costs for existing, early-generation wind equipment should be $\$ 800-900 / \mathrm{kW}$ of capacity, which would constitute a capital cost contribution to the cost of electricity generation of about $\$ 0.025-$ $\$ 0.035 / \mathrm{kWh}$, depending in part on the cost of capital. AB 1890 transition funds invested in the re- 


\section{The Implications of Deregulation for Biomass and Renewable Energy in California}

powering of old, inefficient, and expensive-to-operate California wind farms clearly have the potential to help provide for a sustainable future generating option. The CEC determined that re-powerings that continue to operate under existing standard-offer PPAs would be classified as existing generating sources, and those that opted to forego their PPAs would be classified as new generating sources, for purposes of qualifying for different categories of the transition funds.

\section{Landfill Gas, MSW, Tire-Derived Fuel, Small Hydro}

Some of the cost of converting landfill gas to electricity is attributable to landfill management operations, to comply with existing federal and state regulations for the collection and disposal of landfill gas. The portion of the cost that should be assessed to the electric ratepayer is difficult to determine because of this accounting difficulty. In effect, this situation represents an interesting parallel with the objectives of establishing cost-shifting mechanisms for solid-fuel biomass, discussed later. In the case of landfill gas, the environmental mitigation of landfill-generated emissions is already mandated. The question facing each landfill operator is whether to meet requirements at lowest cost by flaring, or at higher cost by conversion to energy, with sales of the energy produced used to offset the higher costs of compliance. Assigning costs is not as easy as assessing the marginal costs of energy production to the electric ratepayer, because in most cases, due to technical considerations, energy-generating facilities do a more extensive job of gas collection, and hence environmental mitigation, than do lower-cost flare systems. A good deal more analysis needs to be performed to determine whether, and to what extent, landfill gas power generation needs support from the renewables transition funds to achieve economic competitiveness.

MSW and tire-derived fuels are similar to solid-fuel biomass technologies, in that each is a waste material that, in the absence of the energy-generation option, would otherwise require some form of disposal, which in most cases is landfill burial. Some segments of the environmental community do not look favorably on the use of these materials for energy production, mainly because of concerns about emissions. MSW, for example, is specifically excluded as a qualified biomass fuel in Section 1212 of EPACT, as discussed previously. Nevertheless, facilities that burn these types of fuels are subject to regulation and monitoring of their emissions, and assuming that they are operating in compliance with their permits, environmental concerns about them should be directed toward their regulatory requirements.

Hydroelectric generation generally is considered to be a low-cost energy source, so there is a good deal of opposition to awarding renewables transition funds to this source. On the other hand, small-hydro generation, is the only type of hydro that would be eligible for the renewables transition funds, has costs that are highly variable and site specific. In some cases, these costs may be above market, which is one standard for qualification for the renewables transition funds. Treating this technology generally as eligible for renewables funds is very difficult because of the extreme variability in generating costs.

\section{Market Mechanisms and Application of the Transition Funds}

One goal delineated in AB 1890 for the renewables transition funds is to use market-based mechanisms that reward the most cost-effective generation options and foster a market for renewable generating sources. Although a laudable goal, the meaning of the term market-based mechanisms is open to interpretation. The legislation lists several policy options that may be applied, and leaves the CEC to suggest which approaches to use. One suggested alternative is to establish a clearinghouse or marketing agent to identify the most competitive renewable resources providers. This idea was opposed by virtually all parties that participated in the CEC renewables program committee hearing process. 


\section{The Implications of Deregulation for Biomass and Renewable Energy in California}

AB 1890 also suggests, as another possible market-based alternative, that some of the funds be used to provide for a rebate or reduction on consumer bills for purchases from renewable resources providers. This alternative received a good deal of interest at the hearings and workshops. Most of the proposals made to the committee included at least some provision for customer rebates. The proposal from the coalition of green energy providers suggested that the entire renewables transition fund be used to fund customer rebates. Their rationale was that the only real mechanism available for meeting the long-term goals of $\mathrm{AB} 1890$ with respect to renewables was to create a niche market for green energy, and that the way to begin building that market was to use customer rebates to help attract customers to the green market.

One principal limitation to the customer rebate program is that no renewable generating facilities that operate under existing standard-offer contracts would be eligible to participate. Although the goal of having existing facilities give up their standard offer PPAs is appealing to those who would like to see the legacy of the old regulatory system end, no facility owner can be expected to trade-in a secure PPA in favor of the uncertainty of the future market without a substantial inducement, which may exceed the public benefit of the contract retirement in the first place. Customer rebates also do not facilitate the administrative process of ensuring that at least $40 \%$ of the total funds go to extant facilities, and $40 \%$ to new and emerging renewable resource technology providers, as specified in the legislation.

In addition to customer rebates, two market mechanisms were proposed to the committee for paying credits from the renewables transition fund directly to renewable power producers. The environmental organizations proposed that all credits be distributed to renewable power generators on the basis of publicly administered auctions that did not differentiate among renewable technologies. The industry coalition proposal preferred that the credits earmarked for existing generating sources be distributed on the basis of equal allotments for each $\mathrm{kWh}$ produced within technology categories, with specific fund allocations to be made to each technology category. This would allow for differential payments to be made to different technologies, and for the phased decrease of unit payments over the course of the transition period. The industry coalition proposal also called for technology-specific auctions to be conducted for allocating funds for new facilities, rather than having all technologies compete head-on for such funds.

Technology-differentiated credits for existing generating facilities recognize that maintaining the operations of the state's installed stock of renewable generating facilities requires a recognition of the distinct needs of each technology. Moreover, if existing facilities of all technologies were to compete head-to-head for funds, the inherently low operating cost technologies would be able to reap a windfall profit, and the inherently higher-cost technologies might not be able to survive at all.

In the case of supporting the development of new renewable generating facilities, the use of technologyspecific categories implies a form of integrated resources assessment on the part of the entity determining the category-specific allocations. Moreover, a completely open competition promotes AB 1890's goal of rewarding the most cost-effective renewable generating options.

Regardless of the market mechanism employed, the above-market support provided by the renewables transition funds will have to flow to the renewable power generators to allow the continued operation of renewable generating sources in the future competitive market. If the credits are provided as customer rebates, this will allow green energy providers to pay more for renewable generating sources to ensure that their portfolio maintains the level of renewables promised required for their customers. An important consideration for all the programs that may be deployed is to strive to keep administrative costs to a minimum, to apply as much of the funds as possible to the production of renewable electricity. 


\section{The Implications of Deregulation for Biomass and Renewable Energy in California}

\section{Existing Versus Emerging Technologies}

In drafting $\mathrm{AB} 1890$, the California legislature differentiated between existing renewable generating facilities, and "new and emerging" renewable resource technology providers. Each classification was guaranteed at least $40 \%$ of the renewables transition funds; the remaining $20 \%$ would be distributed between the two, according to the recommendations of the CEC. The banding together of new and emerging technologies into the same category led to more controversy than the question of how to allocate the optional $20 \%$ of the funds.

Steven Kelly, of the Independent Energy Producers Association, was a key contributor to the crafting of the legislation. He claimed during a CEC renewables committee hearing that the term "emerging" was thrown in near the end of the legislative process to ensure that such technologies were not precluded from participation in the allocation of renewables transition funds. He asserted that the transition funds were never viewed as a major vehicle for the commercialization of emerging renewable generating technologies.

Advocates of emerging renewable technologies, however, asserted that transition funding for emerging technologies was the best, if not the only, pathway to fulfilling the goals of the legislation to lay the groundwork for the development of a renewables industry that would be able to continue its growth and development into the future, well beyond the period during which transition funding for renewables would be available.

In other words, a major philosophical debate ensued between advocates of using the renewables transition funds for the further deployment of current renewable technologies, and advocates of using the funds to deploy and commercial emerging technologies. Applying the funds primarily to the further deployment of renewable generating facilities using existing technologies would maximize the amount of renewably produced energy from facilities aided by the transition funds. Applying the funds more extensively to emerging technologies would lead to less energy generated from facilities aided by the funds, but offers the hope that new, competitive technologies would be hastened to market readiness, whose deployment would therefore continue to grow beyond the life of the renewables transition funds.

Both positions on this issue are valid and compelling, making the internal allocation of the portion of the funds allocated to "new and emerging" generating sources between existing and emerging technologies very difficult. New renewable generating sources developed with either existing or emerging technologies inherently have costs that are above market. Otherwise, there would be no need to provide transitional funding for renewables. The difference is that the existing renewables are, in general, farther along the learning curve, and have lower costs than technologies in the emerging category. Technologies in the emerging category, however, because of their earlier stage of commercial development, have a greater potential for effectiveness that will be accomplished through accelerated deployment of these systems, which can be fostered through use of the transition funds.

The Union of Concerned Scientists, impressed by arguments on both sides of the controversy, suggested a compromise in which the emerging technologies would be allocated a greater share of the renewables transition funds than was favored by the advocates of the existing renewables technologies, but considerably less than requested by advocates of the emerging technologies. A key part of the compromise was that a significant portion of the public interest R\&D funds provided for by $A B 1890$ would also be applied to emerging technologies, to provide for their accelerated commercialization. The $\mathrm{R} \& \mathrm{D}$ program, like the renewables program, was assigned to the CEC by $\mathrm{AB} 1890$. However, because of 


\section{The Implications of Deregulation for Biomass and Renewable Energy in California}

the very short time frame available to the CEC to produce plans and reports on both topics, its objectives could not be extensively integrated.

\section{CEC Report to the Legislature}

On March 20, 1997, the CEC held a final hearing on the AB 1890 report to the legislature, and formally adopted the report. The report was delivered to the Senate Committee on Energy, Utilities, and Communications on April 8, 1997, at a public hearing. This committee is headed by Senator Steven Peace, whose joint conference committee developed $\mathrm{AB} 1890$. The recommendations of the report are being incorporated into legislation as SB 90 to allow the CEC to begin implementing the programs for renewables transition support.

The CEC report recommends the following overall allocation for the renewables transition funds:

- Existing Renewable Generating Sources $\quad 45 \%$

- New Renewable Generating Sources $\quad 30 \%$

- Emerging Renewable Generating Sources $\quad 10 \%$

- Customer Rebates for Green Energy Purchases $\quad 15 \%$

Funds for existing generators are divided into three technology tiers to recognize the differential needs of the various renewable generating technologies. Tier I includes solid-fuel biomass, solar thermal, and MSW generators. Tier II is for wind generators. Tier III includes geothermal, small hydro, and landfill gas generators. Within each tier, eligible generators will receive production credits based on the less of set maximum of values determined individually for each tier and year, the difference between a specified target price and the actual market clearing price, and the amount of the funds available for the tier and period divided by the total amount of eligible $\mathrm{kWh}$ generated.

Funds for new renewables generators will be distributed on the basis of a single or annual auction, in which project developers bid for a 5-year stream of production credits. All renewable generating options compete head-to-head for these funds. Funds for emerging technologies would also be distributed by a simple auction, and could be applied in a varieties of ways, including interest rate or capital cost buydowns, customer rebates, and production credits. The CEC will make the determination as to which technologies are eligible to participate in the emerging category. Funds for customer incentives will be paid on a per $\mathrm{kWh}$ basis, based on the amount of renewable power purchased by each eligible customer. Rebates will be limited to $\$ 1,000$ per month per customer, limiting the appeal of the program to larger commercial and industrial customers.

The funds allocated to each category are further differentiated by the timing of their allocations for each of the 4 transition years during which the funds will be collected (1998-2001). The funds for existing generators will dominate the uses of the funds during the first year of the transition period, but the relative amount allocated to these generators will decline during each year, as the eligible generators are progressively weaned from transition support to no support by the end of the transition period. Funds for new technologies and customer rebates increase each year during the transition period, as a natural lag time is anticipated and increasing demands are expected for these funds as the transition period progresses. Emerging technologies are allocated a flat $10 \%$ of the funds during each of the 4 transition years, providing a stable program during the entire transition period. 


\title{
Cost-Shifting Measures for Biomass Energy Production
}

\begin{abstract}
AB 1890 recognizes explicitly the special environmental services that are provided by biomass power generation in the areas of reduction of open burning of agricultural residues, reduction in landfill loading, and reduction of forest fire risks in the state's forest lands. Implicitly, the legislation also recognizes that biomass generators will have trouble competing in the future deregulated power market, because of the inherently high costs of biomass power generation compared to those of competing sources such as hydroelectric and natural gas. To address this discrepancy, $\mathrm{AB} 1890$ directed Cal/EPA to report to the legislature on strategies for shifting some of the cost of biomass power generation away from the electric ratepayer, and onto beneficiaries of biomass power production. The Cal/EPA report was put on the same reporting schedule that was given to the $\mathrm{CEC}$ for its report on recommending how to allocate renewables transition funds.
\end{abstract}

$\mathrm{Cal} / \mathrm{EPA}$ was directed to consult with a broad range of interested stakeholders to prepare its report on cost-shifting strategies for biomass power production. Part of the mandate included a directive to quantify the expected benefits of cost shifting, as well as the costs, to determine whether the benefits outweigh the costs. Implementation requirements and transition issues were also to be considered.

\section{The Need for Cost Shifting for Biomass Energy}

Determining the extent of the need for cost shifting to allow California biomass power producers to remain viable in the future competitive electric generation market is extremely difficult to do. Cost shifting needs for biomass power production are functions of several important factors, including:

- Revenues paid to power producers for electricity and capacity sales

- Type of biomass fuel used

- Size of the overall biomass fuels market

- New versus existing biomass generating facilities

\section{Revenues Paid To Power Producers for Electricity and Capacity Sales}

Twenty-seven biomass power plants currently operate in the state, three-quarters of which are selling power under Interim Standard Offer number 4 (SO\#4) PPAs with PG\&E or SCE. After the completion of a 10-year fixed price period, the $\mathrm{SO} \# 4$ s provide for the payment of electricity revenues based on short-run avoided cost (SRAC) rates, and capacity revenues based on a levelized, 30-year contract price. Most of the seven non-SO\#4 operating facilities sell power at SRAC rates without any capacity revenues, or with the limited as-available capacity payments that currently are offered by the utility companies. All the non-SO\#4 facilities that still operate produce most or all of their own fuel, and all use some or all of their net electricity output for on-site retail displacement, or over-the-fence industrial sales.

In addition to these 27 facilities, an additional 15 were shut down over the past several years after PPA buyouts, and would be able to restart and resume full operations if conditions warranted. With two exceptions, these facilities have completely abrogated their standard offer power contracts, and would have to either sell through the new power exchange at prices that will be set hourly, or they would have to make new deals with power purchasers or marketers. Moreover, several of the operating biomass power 
plants are generating at levels well below their rated capacity, and would be able to increase their output if a suitable purchaser could be located.

Since world oil prices crashed in 1985-1986, SRAC rates in California have hovered in the range of $\$ 0.020-\$ 0.035 / \mathrm{kWh}$, as shown in Figure 1. SRAC rates have been particularly volatile during the past year, a result in part of increasing uncertainty in energy markets resulting from the passage of restructuring legislation in September 1996, and supply bottlenecks that hit the natural gas industry around the beginning of 1997. SRAC in Pacific Gas and Electric (PG\&E) has averaged about $\$ 0.029 / \mathrm{kWh}$ for 1997 , and about $\$ 0.033 / \mathrm{kWh}$ for SCE. Current rates are just about at these levels for both utilities.

The CEC commissioned a study by LCG consulting, Inc. (R. Deb et al. 1996), that projected future SRAC rates in California as the competitive electric generation market evolves. Table 3 shows annual average SRAC rates for PG\&E and Southern California Edison (SCE) for the past 5 years, as well as LCG projections for 1998, 2001, and 2006. In current year constant dollars, the projections show the average SRAC rates for both regions staying level at about $\$ 0.03 / \mathrm{kWh}$ throughout the period of the projections.

Revenues paid to biomass generators for power sales under existing contracts are differentiated by season (summer and winter) and time of day (peak, partial peak, off peak, super off peak), to reflect fluctuations in system-wide electrical demand, which determine the marginal resources dispatched at any given time. The time-of-use differentiation is more extreme for southern than for northern California, mainly because of the greater contribution of hydroelectricity in the north, which produces at a maximum level during the summer when the use of irrigation water is at a maximum. Table 4 shows the time-of-use differentiated rates for SCE and PG\&E based on 1997 average prices.

SO\#4 firm capacity prices average about $\$ 0.015-\$ 0.020 / \mathrm{kWh}$, depending on the year of startup for the facility, and its operating performance during summer peak hours. Like energy rates, capacity prices are differentiated by time-of-use period, although for capacity payments the skewing is far more extreme. More than $80 \%$ of all capacity payments are earned during summer peak hours, and no capacity credits are earned for power generated during off-peak and super-off peak hours during any part of the year.

\section{Type of Biomass Fuel Used}

The California biomass power industry uses four categories of biomass fuels:

- Wood processing residues (mill residues)

- In-forest residues (harvesting residues, thinnings, other forest management residues)

- Agricultural residues (orchard removals and prunings, straws, processing residues)

- Urban wood residues (tree and brush trimmings, construction and demolition residues)

Each type of residue has its own characteristic cost, availability, and supply curve, and the use of residues of each type provides its own characteristic package of environmental services. These are summarized in Table 5. Figure 2 shows the time history of the use of the four categories of fuel in California since 1980. Currently, largely because of the closure of approximately $20 \%$ of the operating biomass power generating capacity in the state, all four fuel types are being used at or near the lowest level shown in the table for the 1990s. 


\section{The Implications of Deregulation for Biomass and Renewable Energy in California}

Supply curves have been constructed for each fuel type, based on available data for the past 10 years. Partly because some fuel used during this period has been sold subject to long-term contracts of as long as 5 years, which tended to be well outside of market price by the end of the terms, and because only a limited database is available for each fuel, it is difficult to determine individual supply curves with a high degree of certainty. Nevertheless, linear least-squares fits were performed for each data set, with the results shown in the table, in terms of marginal price changes as a function of quantity changes for each fuel category (slope of curve as measured by changes in fuel price per million bdt change in total amount of fuel used). As the data in the table show, the slope of the supply curve for wood processing residues is less than half of the slope for the other three fuel categories, which are fairly comparable to each other.

Wood processing residues form the backbone of the fuel supply for the California biomass power industry, and are the cheapest form of fuel available in the state. Even with the contraction in state-wide wood-products manufacturing during the $1990 \mathrm{~s}$, mill residues remain the predominant source of biomass fuels. Many biomass power generating facilities were developed in conjunction with or near major sawmills, minimizing the transportation required to deliver this material to the power plants. Collection and handling of residues are normal parts of milling operations, and the residues can be processed into fuel form with standard equipment, such as wood hogs. In the absence of energy uses, this material would either be burned in inefficient sawmill boilers to provide kiln and process steam, or landfilled. Classic disposal practice was combustion in teepee burners, but this method has been phased out in response to increasingly stringent air quality standards.

The contraction in biomass power generation in California since restructuring was initiated in 1994 has had very little effect on the use of wood processing residues as fuel. As the least-cost fuel source, wood processing residues continue to be used as available. Wood processing residues are not only the lowestcost biomass fuel source in the state, they also have the flattest supply curve, with a marginal cost of supply changes of approximately $\$ 8.00$ per million bdt change in state-wide fuel use, which is less than half the level that is characteristic of the other biomass fuel. The ultimate supply of wood processing residues available for fuel use is determined by the amount of forest products manufacturing. As a result, the potential for increasing this source of fuel is limited.

In-forest residues are the highest-cost source of biomass fuels in California. As a result, their use has been the most severely affected by the contraction in biomass fuel use, falling by almost $65 \%$ since 1994 . In-forest residues are expensive to produce because of their generally remote location, and the high costs of residue harvesting, processing, and transportation. On the other hand, their environmental benefits are enormous. The state's forests are overstocked with biomass compared with pre-industrial, "natural" levels. The excessive fuel loading greatly increases the risk of catastrophic wildfires, and reduces the amount of water production from forest lands for environmental and human consumption.

Because of the vast amount of in-forest biomass in California, relative to the amount of this material that currently is used for fuel, the potential for increasing fuel supplies from this source is great. At current levels of in-forest biomass fuels consumption, approximately 60,000 acres per year are being thinned. The U.S. Forest Service, which manages approximately half the state's commercial forest land, would like to be able to treat 250,000 acres per year of land for fire hazard reduction, although it does not currently have the budget to do so.

Agricultural residue fuels, the bulk of which are orchard removals and prunings, are an important fuel source in California. Many of the biomass power plants in agricultural regions were built subject to construction permits that contained requirements for the use of minimum quantities of agricultural residues fuels. These facilities are given offset credits for $\mathrm{NO}_{\mathrm{x}}$ and other pollutants based on the diversion 


\section{The Implications of Deregulation for Biomass and Renewable Energy in California}

of agricultural residues from open-field burning to controlled combustion in the power plants, where the emissions are greatly reduced.

Agricultural residue fuels are approximately twice as expensive as wood processing residue fuels. Moreover, the marginal cost of increasing the supply of agricultural residue fuels is high because agricultural residue fuels are supplied by two types of materials, which have very different costs of production. Orchard removals, which provide whole tree chips at harvesting densities usually exceeding $20 \mathrm{bdt}$ per acre, are relatively inexpensive to convert to fuel. This source has been used extensively as a fuel supply during the past decade. Orchard prunings are often available at harvesting densities of approximately $1 \mathrm{bdt} / \mathrm{acre}$, and are more difficult to convert to fuel form due to the "stick-like" nature of the resource. Prunings provide the major part of the marginal supply of agricultural residue fuels. Only a small proportion of the orchard prunings currently produced in California are diverted to power plant fuel use, so the potential to increase supplies from this source is great.

Urban wood residues, which would be landfilled if not diverted to fuel use, provide the second largest component of the California biomass fuel supply after wood-processing residues. In the current market, urban waste wood fuels are fairly inexpensive. However, the economics of producing urban biomass fuels is very difficult to isolate, because in many cases these fuels are produced as just one product of a complex materials recovery operation, where the overall costs of the operation are difficult to apportion among the various product streams.

Because of a variety of circumstances, including the rapid increase in the demand for biomass fuels during the period 1988-1991, and the passage in 1990 of AB 939, California's solid waste diversion law, major efforts were made to develop the urban waste wood biomass fuel supply. Urban waste wood fuel use has contracted over the past few years, in response to decreasing overall demand for biomass fuels, so the potential to increase its use to the levels that were being achieved during the early part of the decade should be possible. Significant increases beyond this level, however, probably will not be forthcoming, resulting in the designation in Table 5 of moderate potential for increasing the use of urban waste wood biomass fuels in California.

\section{Size of the Overall Biomass Fuels Market in the State}

The overall demand for biomass fuels has a major impact on their price, with the result that the marginal cost of increasing biomass power production is a function of the prevailing level of biomass fuel demand. Figure 3 shows the overall biomass fuel supply curve, with annual data for fuel price and use from 1980 to the present. The data have been supplied under confidentiality agreements by approximately half the biomass power plants in the state. A previous version of this curve was published previously (G. Morris 1997), based on survey work performed during mid 1996. This curve is an updated version of the supply curve, with corrected, end-of-year data for 1996, and projected data for 1997, included.

The California biomass fuel-supply curve presents an interesting paradox for biomass policy development. The special environmental services associated with biomass energy use, which provide the rationale for providing public support for biomass power generation over and above what is offered for other renewable generating sources, are provided in direct relation to the amount of biomass used for fuel. However, the greater the amount of biomass fuel used, the greater the unit cost of support necessary to support such levels of fuel use. This paradox is further exacerbated by the fact that, at a given installed generating capacity for biomass power production, the marginal use of fuel occurs during off-peak hours when power revenues are at a minimum. 


\section{The Implications of Deregulation for Biomass and Renewable Energy in California}

Current biomass fuel use is at approximately 3.25 million bdt/year. According to the supply curve, the equilibrium fuel price corresponding to this level of demand is $\sim \$ 24.50 / \mathrm{bdt}$. This represents a fuel-cost contribution to electricity production of $\sim \$ 0.022 / \mathrm{kWh}$. Increasing the level of biomass fuel consumption 1 million bdt per year, to a total of 4.25 million bdt/year, would increase the average cost of fuel to $\sim \$ 31.50 /$ bdt based on the historical supply curve, a fuel-cost contribution to electricity production of $\sim \$ 0.029 / \mathrm{kWh}$. In other words, it would take a subsidy of $\sim \$ 0.007 / \mathrm{kWh}$ over and above what might be needed to maintain the industry at current production levels to stimulate an increase in fuel use of 1 million bdt/year.

\section{New Versus Existing Biomass Generating Facilities}

The capital component of the cost of electricity production at biomass power generating facilities is fundamentally different for existing versus new generating facilities. California has a fleet of 42 operable biomass power generating facilities, with a combined generating capacity of $\sim 800 \mathrm{MW}$. Twenty-seven of the facilities, representing $\sim 540 \mathrm{MW}$ of capacity, are currently in operation; the remainder currently are shut down, but could be restarted if economic conditions warranted.

The existing fleet of facilities, most of which were placed into service between 1983 and 1992, have been substantially or fully amortized, so their capital cost contribution to the cost of electricity production is lower than it was during their early years of operation. A new biomass generating facility has a capital cost of approximately $\$ 1,350-1,600 / \mathrm{kW}$ of capacity, which translates into a capital cost contribution to the cost of electricity production of approximately $\$ 0.025-\$-0.045 / \mathrm{kWh}$. For facilities that have operated for at least 10 years, this cost is reduced by one-third to one-half, to a level of approximately $\$ 0.014$ $\$ 0.02 / \mathrm{kWh}$. Thus, new facilities would require support of approximately $\$ 0.015 / \mathrm{kWh}$ over and above that given to existing facilities to be competitive.

\section{Cost Shifting Requirements}

The cost of biomass power production has three components: a capital cost contribution, a fuel-cost contribution, and a non-fuel O\&M cost contribution. The capital cost and fuel cost contributions have been discussed earlier. The non-fuel O\&M cost of biomass power production is the easiest of the three to estimate, and shows the least variation among facilities. Based on an extensive survey of 42 biomass generating facilities in the United States and Canada (G. Morris 1994), half of which are located in California, non-fuel O\&M costs for biomass power generation vary from approximately $\$ 0.020$ $\$ 0.028 / \mathrm{kWh}$ for modern, well-run facilities.

Table 6 summarizes the information presented earlier for the costs and revenues available for biomass power production in California, as a function of fuel type used, for existing facilities with an SO\#4 PPA for which the fixed-price period has ended. The bottom of the table shows the resulting requirements for cost shifting that would be required to allow the generators to operate in the competitive electricity market of the future.

The fuel-cost data shown in the table are based on the cost of fuel provision, as detailed in Table 7, not on the current prices paid for these fuels. The costs presented in the table are based approximately on current levels of fuel use, and would increase if the amount of fuel used in each category were to increase, for example due to longer average hauls, and the need to procure residues that entail more expensive harvesting and collection operations than the average currently used. The only fuel source that is priced at a level that is significantly over cost is wood processing residues, which earn a premium profit due to 


\section{The Implications of Deregulation for Biomass and Renewable Energy in California}

market effects. The other sources of fuel currently are priced near their equilibrium market level, given the current size of the market. If policy makers believe that it would be desirable to increase the amount of biomass used for fuel, the amount of cost shifting $(\$ / \mathrm{kWh}$ or $\$ / \mathrm{bdt})$ needed to stimulate this increase would increase in accordance with the supply curves presented. For example, to stimulate the market to expand from its present level by 1 million bdt/year, the cost-shifting requirements would increase by approximately $\$ 0.007 / \mathrm{kWh}$, or $\$ 7.50 / \mathrm{bdt}$, for each fuel source.

\section{CIWMB Hearing Process}

To comply with its obligation to report to the California legislature on the benefits of biomass power generation, and on public policy strategies for shifting some of the costs of biomass power generation away from electricity ratepayers, to other classes of beneficiaries, Cal/EPA assigned the task of preparing the report to the California Integrated Waste Management Board (CIWMB), one of its constituent agencies. The CIWMB convened a series of public workshops beginning in late December 1996, to elicit public participation in the formulation of cost-shifting strategies. Interested parties were invited to submit proposed policy actions, which were then opened to scrutiny by all participants. Table 8 presents a list of the workshop dates and topics.

The CIWMB made clear that it would prefer to have participants in the process reach consensus positions to the maximum extent possible, so their proposals would have broad public support. The agency had neither the time nor the resources to perform an independent analysis of the quantified benefits of biomass power production, so it assembled the results of work performed by others. Proposed cost-shifting strategies were solicited from the workshop participants and the interested public.

Three submittals were received by the CIWMB on the subject of the quantification of the benefits of biomass power production. The reports included:

- California Biomass Energy Alliance, Biomass Energy in California: Valuation of External Benefits, filed with the CEC and the CIWMB, Dec. 1996.

- Morris, G., The Environmental Costs and Benefits of Biomass Energy Use in California, NREL report No. NREL/SR-430-22765, May 1997.

- Natural Resource Strategy Services, Benefits of Biomass Power in California, draft report, Feb. 1997.

Each report analyzes environmental benefits from a unique perspective, and uses its own analytical approach, so the results of the reports are difficult to compare directly. Nevertheless, all the reports, and all the information presented at the public workshops, agreed that the benefits of biomass power production are worth a great deal to California, and are worthy of efforts to preserve them. Even without being able to put exact measures on the benefits, it was widely agreed that the benefits are worth considerably more than the value of the cost-shifting measures that would be required to allow the power plants to be viable in the coming competitive electricity market. No participant at the CIWMB workshops expressed any reservation about that conclusion. 


\section{The Implications of Deregulation for Biomass and Renewable Energy in California}

\section{Cost-Shifting Measures Proposed to the CIWMB}

The California Biomass Energy Alliance (CBEA) presented a series of potential cost-shifting measures to the workshop participants for group consideration. Strategies were also proposed by the CIWMB staff, and by other parties participating in the CIWMB workshops. Most of the proposed measures could be implemented at the local or state jurisdictional level, but at least one measure would require implementation at the federal level.

The CIWMB staff constructed a set of 10 cost-shifting measures from the submittals and ideas presented at the workshops. The proposed cost-shifting measures, classified according to the ranking of the $\mathrm{Cal} / \mathrm{EPA}$, include:

\section{Reasonable Feasibility/Impact}

- Full diversion credit for energy use of diverted landfill waste wood

- Credits for wildfire prevention activities

- Modification of the federal biomass energy production tax credit

\section{Potential Feasibility/Impact}

- Credits for increased water production from improved watershed management

- Tax credit for the use of agricultural fuels

\section{Minimal Feasibility/Impact}

- Emissions reduction credits for reduced open burning

- Open burning permit fees

- Tipping fee surcharge on waste disposal

- Diesel fuel tax rebate for fuel production activities

- Minimum purchase requirement for government facilities for biomass energy

Three of the proposed cost-shifting policies apply to all types of biomass fuels; the other seven are targeted at particular types of biomass fuels. As detailed earlier, different types of biomass fuels in California have different levels of cost-shifting needs, in terms of, for example, dollars per ton of fuel, to remain viable fuels in the marketplace. Sawmill residues have the lowest level of need for cost-shifting support; in-forest residues have the greatest need.

\section{Cost-Shifting Measures Applicable to All Biomass Fuels}

Three cost-shifting measures have been considered that would apply to all categories of biomass fuels used in California. These measures include modifying the federal renewable energy tax credit to apply to existing biomass facilities using all types of biomass fuels, extend diesel fuel tax rebates to biomass fuels production and delivery, and establishing a minimum purchase requirement for electricity generated from biomass fuels for state-owned facilities. 


\section{The Implications of Deregulation for Biomass and Renewable Energy in California}

\section{Renewable Energy Tax Credit}

EPACT created a category of tax credits called IRS Code Section 45, Electricity produced from certain renewable resources $(\S 45)$. New wind and biomass facilities that are put into operation between 1993 and 1999 and sell their power output to others are eligible to claim the $\S 45$ credit, which currently is worth approximately $\$ 0.016 / \mathrm{kWh}$. For biomass systems, the $\S 45$ credit is further limited by the provision that the biomass used for power production must be derived from "closed loop" sources, which means that the fuel must be grown specifically for use as a fuel. Virtually no biomass power plant in the United States today derives a significant quantity of its fuel supply from closed-loop sources. To date, the $\S 45$ credit has not been claimed for any solid-fuel biomass power facility.

To allow the $\S 45$ credit to benefit the existing biomass energy industry in California and across the United States three significant modifications to the law are required. The necessary modifications include: (1) Drop the closed-loop restriction in the law; (2) Remove the sunset date on the $\S 45$ credit; and (3) Allow existing facilities to claim the $\S 45$ credit. Such action would recognize that the special benefits of biomass energy production accrue particularly from the disposal of wastes and residues in an environmentally superior manner, and that the provision of these benefits in the long run requires due compensation, or they will be lost.

\section{Diesel Fuel Tax Rebate}

Diesel fuel that is used for agricultural or forestry operations conducted in the field, off the state highway system, is exempt from state fuel taxes, with purchasers of fuel for qualified uses given a tax rebate. Diesel fuel tax rebates could also be extended to all biomass fuel production and transportation activities, which would reduce the cost of delivered biomass fuel by approximately $\$ 010-\$ 0.15 /$ ton of fuel, which represents a modest amount of cost shifting. The costs of this measure would be borne by the taxpayers.

\section{Minimum Purchase Requirement}

The California biomass energy industry has pioneered the effort to create a mandated minimum purchase requirement for electricity generated from biomass fuels, and from renewables in general, as a component of electricity restructuring programs. A minimum purchase requirement was included in the California Public Utilities commission's (CPUC) 1996 restructuring program, and was under legislative consideration in the state legislature as $A B$ 1202, which passed in the Assembly in 1996. However, the legislative conference committee that crafted comprehensive restructuring legislation at the end of the 1996 session ruled against the inclusion of a minimum renewables purchase requirement, and it is not part of the current program for electricity restructuring.

One proposed cost-shifting strategy for the support of biomass power generation in California would be to create a minimum purchase requirement for biomass-generated power for purchases of electricity. The State of California is a major consumer of electricity, so imposing a minimum biomass purchase requirement could create a significant market niche for biomass power production. The cost would be borne by the taxpayers. Biomass-generated power that is sold under existing standard-offer contracts with the utilities probably would not be eligible for this program, as the energy will be supplied into the newly created power pool on an undifferentiated basis. This type of program would be particularly applicable to the biomass generating facilities that have accepted buyouts of their utility power-purchase contracts, and currently are shut down. 


\section{The Implications of Deregulation for Biomass and Renewable Energy in California}

\section{Cost-Shifting Measures Applicable to Landfill-Diverted Biomass Fuels}

Biomass wastes that can be segregated and converted into power plant fuels make up approximately $15 \%$ of the material that traditionally is disposed of at municipal landfills. California counties and waste districts are under mandate to achieve a waste diversion rate of $50 \%$ by the year 2000 , as measured against the baseline year of 1990. Two proposals were made for the cost-shifting support of converting landfill biomass waste into biomass fuels. One proposal is to broaden the amount of diversion credit that can be earned for fuel production. The other is to impose a fee or surcharge on all waste disposal, or on the disposal of loads that contain high proportions of recoverable waste wood, with the funds collected to be used to support fuel production operations.

\section{Waste Diversion Credit}

AB 939, the Integrated Waste Management Act of 1989, requires all jurisdictions to reduce the amount of waste disposed of in landfills in California by $50 \%$ by the year 2000 . Each jurisdiction must calculate the baseline amount of waste generated in 1990, and compare it to the amount of waste diverted in the year 2000. As currently constituted, the law limits the proportion of the total amount of diversion that may be used as a fuel to one-fifth $(20 \%)$ of the total diversion credit, or $10 \%$ of the total amount of waste. If biomass fuel demand can absorb more than $10 \%$ of the total amount of waste in a particular jurisdiction, the amount over 10-\% will not be counted toward compliance with its diversion requirement. In typical California urban solid waste, $15 \%-20 \%$ of the total amount of material is suitable for conversion into biomass power plant fuel.

The solid waste diversion credit proposal is to remove the $10 \%$ limit on the counting of fuel use toward a jurisdiction's diversion credit, to allow each jurisdiction to produce as much power plant fuel as market conditions dictate, while receiving full credit for this diversion from landfill disposal. Lifting the restriction on recycling credits that can be attributed to biomass fuel production will not require the input of any public funds, nor will there be any direct cost to the waste disposal industry. In fact, it should have a positive effect on waste disposal costs, by extending the range of the options that jurisdictions have available to them for compliance with diversion goals.

\section{Tipping Fee Surcharge}

Waste that is disposed of at the state's landfills is assessed a charge that includes fees for the landfill owner/operators, and fees that go to the state and, in some cases, local jurisdictions. There are a variety of ways in which a tipping fee surcharge could be used as part of a cost-shifting strategy for benefiting the conversion to fuels of segregateable materials. One proposal, which met with considerable resistance at the workshops, would be to impose a new surcharge on all solid waste disposed of in the state, which would provide funds that could be used to help underwrite the cost of fuel production from segregateable biomass wastes.

Another proposal that was advanced at the CIWMB workshops uses the threat of a new disposal fee to discourage waste collection practices that make it expensive for transfer station and landfill operators to produce fuels from waste wood. The cost of biomass fuel production includes both costs to segregate and clean up the waste wood material stream, and the cost of chipping and delivery. This proposal would impose a fee on waste loads that contain a substantial fraction of waste wood, but are contaminated with a substantial fraction of non-wood material, in an effort to encourage waste generators and collectors to provide a cleaner in-coming waste stream to the landfill. Cleaner waste wood is cheaper to handle before chipping and shipment. The drawback to such a system is defining and administrating what constitutes contaminated waste wood loads. 


\section{The Implications of Deregulation for Biomass and Renewable Energy in California}

\section{Cost-Shifting Measures Applicable to Agricultural Biomass Fuels}

The open burning of agricultural residues in California's major agricultural regions is a major source of air pollution in these regions, many of which are out of compliance with federal standards for some criteria air pollutants. Currently, open burning is a free right to farmers, and widely practiced as the leastcost option for the disposal of agricultural field residues, including vast quantities of woody materials, such as orchard and vineyard prunings.

Three concepts were advanced at the CIWMB workshops to provide funds that could be used to off set the difference in cost between biomass fuel production and open burning of agricultural fuels. One proposal would deduct the cost from state general funds by providing a tax credit to producers or users of agricultural fuels. Another would charge the state's farmers, the generators of the residues, for the needed funds, by imposing a new fee on open burning. The third would attempt to share the cost between farmers and industrial polluters, by creating an emissions trading system.

\section{Agricultural Fuels Tax Credit}

The first proposal advanced was for creating a state tax credit to divert agricultural residues from open burning to fuel production. This policy was introduced in the state legislature in 1997 as $A B 1513$, which would have provided for a maximum tax credit of $\$ 30 / \mathrm{bdt}$ for agricultural prunings that are converted to biomass fuels. AB 1513 passed the Assembly during 1997 but died in the Senate, and probably will be reintroduced during the 1998 legislative session. The AB 1513 tax credit would be restricted to fuels made from agricultural prunings, which currently make only a very small contribution to the market. The tax credit approach spreads the cost of the program across all state taxpayers, who collectively benefit from improved air quality.

\section{Open Burning Permit Fees}

The only current restriction on open burning of agricultural residues is that such burns are restricted to approved burn days, which are selected by air pollution control agencies when ambient pollution levels are low, and atmospheric conditions are conducive to rapid dilution and/or clearing of the pollutants generated by the open burning. One proposal made to the CIWMB would be to force the farmers to bear collectively the marginal cost of fuel production for a portion of the state's agricultural residues, by imposing a new permit fee for open burning. Individual farmers would be able to bid into the available fund of money collected from the fees for diverting residues from open burning to fuel production. The farmer would benefit in two ways by converting his residues to fuel. First, he would be able to collect a fee per ton of material diverted, which would be regulated by a bid mechanism, and funded by payments of the permit fees. Second, the material that is diverted would not be subject to payment of the burn permit fee. This measure would be opposed vigorously by the farming community, who would see their cost of production increase, with no countervailing competitive benefit.

\section{Open Burning Reduction Credits}

A proposal to create an emissions trading system to eliminate open burning of residues garnered the least amount of support among participants in the CIWMB workshop process. In this system, new industrial emitters, or emitters that are now under regulatory pressure to decrease or offset some of their current emissions, would be able to pay farmers to convert contracted-for quantities of their agricultural residues into power plant fuels, thus withdrawing the residues from disposal by open burning. The attractive feature of this system is that the cost of subsidizing fuel production is paid for by industrial polluters, and controlled by market forces. The drawback is that in emissions trading markets there is an excess of 


\section{The Implications of Deregulation for Biomass and Renewable Energy in California}

unsold credits, and little or no demand for credit purchasing. In other words, there is little hope of this mechanism providing any significant funding that could be used to shift the cost of electricity production from agricultural residues away from electric ratepayers in the foreseeable future.

\section{Cost-Shifting Measures Applicable to In-Forest Biomass Fuels}

The long-term buildup of biomass in forests in California and the entire western United States to levels much higher than would exist in undisturbed, native forests, has become a major environmental concern. Although periodic moderate fires are normal to western forest ecosystems, the excess biomass loading in the forests is causing a measurable increase in the incidence, extent, and severity of high-intensity wildfires, which are not natural components of the ecosystems. These fires are causing extensive losses of environmental quality and destruction of property values, and increasingly are threatening homes and neighborhoods. In addition, it is now widely believed that the overloading of biomass is interfering with ecosystem functioning in many of the region's forest watersheds, reducing the amount of water that is available for downstream environmental and consumptive purposes.

\section{Wildfire Prevention Credits}

Wildfire prevention in California's forests is a high priority of the California Department of Forestry and the U.S. Forest Service, as well as most private owners of forest lands. California's Fire Plan (CDFFP 1996) emphasizes the use of thinning and clearing operations as a cost-effective means of reducing the risks of catastrophic wildfires by removing excess biomass from forests before catastrophic wildfires start. Such treatments, however, are expensive.

The major option available for reducing the forest fuel loading is prescribed burning of biomass in the forest. The U.S. Forest Service recently allocated funds to increase its use of prescribed burns. However, prescribed burns of forests in their present condition is risky, can lead to significant kills of the desirable growing stock, and can produce large quantities of air pollutants, entailing a risk of initiating uncontrolled wildfires.

Mechanical thinning operations, although more expensive than simple prescribed burns, offer a superior alternative for fuels reduction. In some cases, mechanical thinnings can provide the desired fire risk reduction; in other cases, prescribed burns will be conducted after thinnings to finish the job. Thinnings carried out before prescribed burns, in which ladder fuels and other materials are removed, significantly reduce the risks of the prescribed burn killing the growing stock that is supposed to be enhanced, and of initiating larger, uncontrolled fires. The exact treatment that is appropriate or optimal for any given tract of land is very site specific.

At the height of the California biomass fuels market during the early 1990s, when biomass power plants were paying as much as $\$ 40 / \mathrm{bdt}$ or more for fuel, land owners and managers were able to obtain thinning services essentially for free, because the sales of the resulting fuel completely covered the cost of thinning, processing, and delivery. As fuel prices have fallen over the past several years, land owners and managers have had to accept a portion of the cost of fuel production, which is no longer met in full by the sales of the biomass fuel. This represents a form of cost shifting that has occurred in the absence of any directed policy. However, the result has been a significant drop in the amount of thinning that has been carried out, which is opposite to the trend that forest managers would like to see.

The wildfire prevention credit proposal would create state and federal budget allocations to provide funds for thinning and chipping operations on public forest lands, both in conjunction with, and supplemental 


\section{The Implications of Deregulation for Biomass and Renewable Energy in California}

to, prescribed burning activities. The proposal also would grant tax credits to private land owners who engage in thinning activities on their own forest holdings.

\section{Water Production Credits}

A broad consensus has formed supporting the concept that forest thinning and other watershed improvement operations could increase the production of both environmental and usable water supplies from the state's major forest watersheds. This is because overstocked forest stands have an evapotranspiration rate that is elevated significantly compared that of undisturbed native ecosystems. Increased evapotranspiration leads to decreased storage and release of water from watershed soils, especially during the summer, when such water is particularly valuable. The concept of increased water production from forest thinning is gaining acceptance, but the science of correlating the impact on a quantitative basis is lagging, which creates a serious deficiency in this area for the making of public policy.

As in the case of allocating funds for fire prevention through thinnings and prescribed burns, it would be in the state's interest, at least conceptually, to expend funds for watershed improvement operations to increase water production. Funds for these activities could be provided from a surcharge on commercial water sales, particularly if the marginal cost of increasing water supplies by this method were clearly lower than the cost of developing new, conventional supplies. Making such a determination will require advancement in the science of correlating thinning operations and other watershed improvements with increased water production.

\section{The Cal/EPA Report to the California Legislature}

After the workshops, the CIWMB produced a first draft of the Cal/EPA report to the legislature on February 11, 1997, which was followed by a second draft on February 26, 1997. These drafts, the second of which was almost 90 pages long, analyzed the history and development of the California biomass energy industry, explored the non-energy benefits of biomass power generation and their economic values, and analyzed a wide range of cost-shifting strategies that had been considered during the workshops.

At about the same time as the CIWMB's second draft was released, the Stationary Source Division of the California Air Resources Board (CARB) released a draft report on The Air Quality Impacts of the Biomass Energy Industry. This report, which was released extremely late in the Cal/EPA Report process, derailed the report preparation process within the Cal/EPA. CARB came to a very different conclusion about the air quality benefits of biomass power generation than all the other participants in the workshop process. CARB was unwilling to make a strong endorsement of the air quality benefits of biomass power generation, citing the difficulty of quantifying impacts, and their site-specific nature. As a result, the CARB report concludes: "The ARB staff does not believe that accurate emission benefits can presently be identified for the diversion of wastes to biomass facilities" (page 3).

CARB and CIWMB are sister agencies within the Cal/EPA, the entity charged with reporting to the legislature on the benefits of biomass power generation, and cost-shifting strategies for preserving the benefits. CARB's reluctance to certify the benefits of biomass power generation with respect to air quality impacts removed air quality benefits from the list of rationales that Cal/EPA could use to justify consideration of cost-shifting measures. This left only landfill diversion as a benefit worth preserving, as certified by the CIWMB. 


\section{The Implications of Deregulation for Biomass and Renewable Energy in California}

CARB staff participated minimally in the workshops hosted by the CIWMB, attending some of the sessions focused on open-burning emissions. They did not bring up their overriding concerns about the difficulty of benefits quantification to the workshop participants, who never had an opportunity to discuss or question these conclusions. Moreover, by delaying the report until after two full drafts of the CIWMB report had already been released, and only days before the participants were expecting the report to be submitted to the Cal/EPA board for its consideration, this effectively denied other participants in the process an opportunity to respond to the CARB report.

Cal/EPA took the reports from CIWMB and CARB under its wing, and deliberated in private. After approximately 6 weeks, during which no new drafts or material of any kind was circulated to the public for comment, Cal/EPA released its report to the legislature in late April 1997 (Cal/EPA 1997). The final report was pared down to just 17 pages of text, and takes a very cautious approach to endorsing future action on cost-shifting strategies for biomass power generation.

\section{A Proposed Implementation Strategy for Biomass Cost Shifting in California}

It is widely acknowledged that the electricity sales revenues that will be available to biomass power generators selling power through the power exchange in the restructured electricity market will not be sufficient to cover the full cost of operations. $A B 1890$ recognizes the special waste disposal benefits that biomass power generation provides, and looks to preserve these benefits by developing policies that shift some of the cost of biomass power generation away from the electric market and onto the beneficiaries of the waste disposal.

The biomass power generation industry in California uses four primary types of residue materials as fuel:

- Sawmill residues

- Agricultural residues

- Urban-wood residues

- In-forest residues

Sawmill residues are the cheapest type of biomass fuel available to the state's biomass power plants. Inforest residues are the most expensive biomass fuel source. In-forest residues are more than twice as expensive to deliver as fuel to the power plants as sawmill residue fuels. Thus the extent of the need for cost shifting is directly related to the type of biomass fuels being used by the power generators.

In recognition of these factors, a two-pronged approach to developing cost-shifting measures for biomass power generation is recommended. The first would be a general support measure for biomass power generation, which would be large enough to provide for power generation using the lowest-cost biomass fuels available. The prong would be a set of targeted support measures for specific fuel sources, based on efforts to solve well defined environmental problems.

The general support measure could be a $\$ 0.01-\$ 0.015 / \mathrm{kWh}$ tax credit for all biomass power generation. Efforts should be continued at the state level to enact a general biomass power generation tax credit, although a change in the federal $\S 45$ credit would accomplish the same thing, and be the optimal solution. Additional, targeted cost shifting could come in a variety of forms, and should be aimed at specific waste disposal goals, rather than to the production of electricity at biomass power plants. 


\section{The Implications of Deregulation for Biomass and Renewable Energy in California}

Targeted cost shifting requirements are currently estimated to be (these are in addition to the aboveproposed general biomass tax credit):

- Agricultural residues: $\sim \$ 0.009 / \mathrm{kWh}$, or $\sim \$ 10.00 / \mathrm{bdt}$

- Urban wood residues: $\sim \$ 0.005 / \mathrm{kWh}$, or $\sim \$ 5.50 / \mathrm{bdt}$

- In-forest residues: $\sim \$ 0.013 / \mathrm{kWh}$, or $\sim \$ 15.00 / \mathrm{bdt}$

Targeted cost-shifting policies should be monitored and/or administered by agencies responsible for resource management or disposal, e.g.:

- Agricultural residues: CARB, AQMDs, Department of Agriculture

- Urban wood residues: CIWMB

- In-forest residues: CDFFP, USDA/FS, CDWR

Funds for the general credit would come from state, or preferably federal, general funds. Funding sources for the targeted cost-shifting measures would have to be developed specifically for each measure. Possibilities include user fees, permit fees, agency allocations, and general funds allocations. In general, targeted cost-shifting measures would provide funds to handlers/processors of fuel, who would then be able to deliver fuels to the power plants at prices that are competitive with the cheapest sources of fuel available to the facilities (the established market price).

Targeted incentives probably will have an effect on the mix of biomass fuels used in the state, which is a desirable outcome. Even during periods when overall demand for biomass fuels has been relatively stable, the mix of fuels was in constant flux, in response to various market signals and shifts. The essential purpose of enacting the various targeted incentives would be to encourage more of the targeted fuel into the overall mix. Each cost-shifting measure will experience diminishing returns as the program is expanded, which acts as an automatic corrective measure.

\section{Targeted Cost Shifting Options}

AB 1890 promotes an "equitable and effective allocation of solid-fuel biomass electricity costs that ensures the retention of the economic and environmental benefits of the biomass industry while promoting measurable reduction in real costs to ratepayers." The waste disposal benefits associated with the biomass power industry have private and public components. The private benefits accrue mainly to the waste generators. The public benefits accrue to all Californians, and include improved air quality, reduced use of landfill space, and improved forest ecosystems with reduced wildfire risks. A major issue that must be addressed in the development of costshifting policies for the California biomass power industry is which class or classes of beneficiaries should shoulder the burden.

Several cost-shifting strategies have been proposed for agricultural residues, urban wood residues, and in-forest residues. For agricultural and urban wood residues, costs can be shifted to either or both of two groups of beneficiaries: the public, who benefit from pollution reduction, or the waste generators, who currently save money on waste disposal by being allowed to avail themselves of environmentally inferior disposal alternatives. 


\section{The Implications of Deregulation for Biomass and Renewable Energy in California}

The case of in-forest residues is different than those of urban and agricultural residues, because the alternative to their fuel is not active disposal, but accumulation in the state's forests. Most of the environmental consequences of in-forest accumulation are borne by the public, who collectively pay the costs of fire fighting, and share the increasing insurance burdens for homes and property located in or near California's forests. The property loss for burned standing timber are borne primarily by the land owner, which for much of California's forest lands is the public, although many private holdings are also at risk.

\section{Urban Wood Residues}

\section{$\underline{\text { Problem }}$}

Clean, separable waste wood accounts for approximately $15 \%$ of the material destined for California's landfills. This material takes up valuable space, is slow to stabilize, and leads to emissions of methane, a potent greenhouse gas. Diverting this material to the biomass power plants saves landfill capacity and eliminates the emissions of methane and odors associated with decay.

\section{Cost-Shifting Strategies}

- Remove cap on diversion credit for fuel use

- Tipping fee surcharge on all waste

- Tipping fee surcharge on "wood-contaminated" fuel

- Grants and/or low-interest loans for grinding equipment

\section{Discussion}

Based on discussions during the Cal/EPA workshops, as well as other available information, any new surcharge on tipping fees that would be large enough to raise meaningful funds for fuel production grants (e.g., $\$ 0.50$ /ton on all waste brought to landfills) will be met with strong resistance from the wastedisposal industry. That is not to say that these options should not be pursued, but it is an important consideration in planning strategies.

Removing the cap on diversion credits for fuel use of waste wood will provide no direct funds for fuel production activities per se, but it should be pursued for two important reasons. First, the cap is simply wrong, and was imposed for purely political reasons. Second, by removing the cap, and enforcing the diversion requirement of $50 \%$ by the year 2000 , the waste disposal industry will be forced to cost-share a host of recycling activities, including fuel production. The competitive market will then determine which set of recycling activities to pursue, and how much waste receivers should charge waste generators. An overall market price for biomass fuel will be established, influenced by factors such as the powerexchange price for electricity and overall demand for biomass fuel, and waste disposers will use that price and other price signals to determine how best to meet the $50 \%$ diversion requirement of $\mathrm{AB} 939$. Removing the diversion cap on fuel use should make compliance with $A B$ 939's diversion requirements less expensive. 


\title{
The Implications of Deregulation for Biomass and Renewable Energy in California
}

\author{
Agricultural Residues
}

\section{$\underline{\text { Problem }}$}

Open burning of agricultural residues, which is the predominant and cheapest disposal alternative available to farmers, is a major source of air pollution in California's major agricultural regions. Diversion of this material to the biomass power plants greatly reduces overall emissions of smoke, particulates, $\mathrm{NO}_{\mathrm{x}}, \mathrm{CO}$, and hydrocarbons.

\section{Cost-Shifting Strategies}

- Agricultural fuels tax credit

- Open burning permit fee

- Tradable emission reduction credits

\section{$\underline{\text { Discussion }}$}

Despite the overall large reduction in pollutant emissions associated with diverting agricultural residues from open-field burning to the biomass power plants, the CARB, in a report appended to the Cal/EPA $A B$ 1890 report to the legislature, was underwhelming in its endorsement of the environmental benefits of biomass power production. Achieving meaningful cost shifting for the diversion of agricultural residues to power plant fuels would be much easier if $\mathrm{CARB}$ were to give a real endorsement to the concept from an air quality perspective.

Farmers, too, could the implementation of cost-shifting measures for fuel use of agricultural residues. Farmers recognize the environmental advantages of combustion in a power plant versus. open burning, and are concerned that a viable power plant option might facilitate the adoption of restrictions on open burning, currently the lowest-cost alternative available to them for disposal of their residues. On the other hand, some farmers recognize the inevitability of open-burning restrictions, and would like to be proactive in responding to the air pollution problem.

An agricultural fuels tax credit proposal currently is making its way through the California legislature. Its future will become clearer during 1998. The viability of other cost-shifting measures might be elevated by the implementation of the federal EPA's proposed particulate standards, the achievement of which in the San Joaquin and Sacramento valleys would be facilitated by a reduction in open burning of agricultural residues.

\section{In-Forest Residues}

\section{Problem}

A long-term buildup of biomass in California's forests, the direct result of a century's worth of successful fire fighting efforts, has fundamentally altered the nature of the forest ecosystems. One ironic side effect of this process is a greatly enhanced risk of catastrophic forest fires, and huge increases in expenditures for fire fighting in recent years. In addition, it is beginning to be recognized that overstocking of biomass in California's forests is leading to diminished water availability in meadows, rivers, and aquifers. Diverting this material to the biomass power plants reduces the risk of catastrophic forest fires, and increases the availability of water for environmental purposes and human use. 


\section{The Implications of Deregulation for Biomass and Renewable Energy in California}

\section{Cost-Shifting Strategies}

- Legislative allocation of funds for fire prevention management activities

- Requirements for density reduction before prescribed burning

- Surcharge on water fees for watershed improvement activities.

\section{$\underline{\text { Discussion }}$}

There appears to be broad-based agreement in the state about the fire risks associated with overstocking biomass in the forests. The state already spends huge amounts of money fighting wildfires, and foresters recognize the desirability of spending money on prevention to reduce expenditures. Their main concern is that prevention funds not be drawn from fire-fighting funds, which are already fully committed.

There are two major options for reducing fuel loading in the forests: prescribed burning, with and without prior removal and conversion to fuels. Prescribed burning alone is the cheaper of the two options, in terms of tons of fuel reduced per dollar of expenditure, but it causes heavy air pollution, losses of value in the surviving growing stock, and entails the risk of accidentally initiating an out-of-control wildfire. Based on the current level of biomass buildup in the state's forests, neither prescribed burning, nor removal for fuel use, can alone solve the problem. The most reasonable solution is to use a mixture of the two techniques, attempting to remove the maximum possible amount of overstocking each year, subject to the constraint of trying to minimized air pollution impacts and accidental wildfire initiation.

The efficacy of the entire spectrum of possible watershed improvement operations, including biomass removal, is well worth further investigation. Based on the current state of knowledge in this area, it is premature to pursue a full-scale program at this time. There is, however, every reason to pursue one or more pilot projects as soon as possible to lay the groundwork for a full program. Californians surely would favor expenditures for watershed improvement over expenditures for building new water projects, to increase and improve water supplies. 


\section{The Implications of Deregulation for Biomass and Renewable Energy in California}

\section{Future Prospects for Biomass and Renewable Energy Production in California}

The California electricity market is about to enter uncharted waters as deregulation begins on January 1 , 1998. Soon, electricity generating sources will compete to supply power to consumers. California's biomass and renewable generating sources will be hard pressed to compete head-to-head with low-cost conventional generating sources without some means to reward their environmental advantages. Their ultimate success will depend in large part on their ability to develop such means.

In recognition of the environmental benefits of renewables in general, and biomass in particular, California's electricity restructuring legislation provides considerable funds to support renewables through the 4-year transition period to full deregulation, during which ratepayers will pay off the stranded costs of the investor-owned utilities. No additional ratepayer-funded support is anticipated to be given to renewables beyond the end of the transition period. A fundamental goal in applying the transition funds is to bring the beneficiaries to a state of preparedness for competition by the end of the transition period.

The legislation acknowledges that biomass power generation may remain uncompetitive beyond the end of the transition period, because of the inherently high operating costs of power generation using biomass fuels. It also recognizes the value of the special waste disposal services associated with biomass power generation. To provide for the long-term needs of biomass power generation, the legislation anticipates the enactment of cost-shifting measures that would allow biomass generators to remain viable earning competitive market prices for their power output, by rewarding them outside of the electricity market for their provision of environmental services. Cost shifting of approximately $1-3$ cents per $\mathrm{kWh}$, depending on the type of biomass fuel used, would apparently accomplish this goal.

In a competitive, open-access market for electricity, renewables producers can attempt to offset their above-market generation costs by selling a premium, "green-energy" product to consumers who are motivated and able to purchase it. A substantial amount of market research has shown a strong interest among electricity consumers in environmentally friendly generating sources, and new electricity services providers are offering green products in California as soon as open access for consumer goes into effect .

Many renewable generating technologies, such as solar, wind, and geothermal, are very capital intensive. Generating sources of this type will have the opportunity to use the renewables transition funds to reduce their long-term capital burdens, so they can remain viable in the competitive market after the transition period, when available market prices will more than offset their operating costs, but may not be sufficient to provide for significant payments toward capital obligations.

In the case of the future of biomass power generation, the focus in the period following the transition period will remain on the existing fleet of generators, as there is little expectation of any new biomass power development in the foreseeable future. A substantial portion of the renewables transition funds will be made available to biomass generators on a decreasing basis through the 4-year period, which should be enough to allow all the currently operating facilities to continue operating, and may stimulate the startup of some of the currently shut-down facilities. As the level of transition support ramps down, the continued success of biomass power generation will depend to a large degree on the extent to which cost shifting measures are enacted. 
The Implications of Deregulation for Biomass and Renewable Energy in California

\section{References}

California Department of Forestry and Fire Protection, California Fire Plan: A Framework for Minimizing Costs and Losses from Wildland Fires, on behalf of the State of California, March 1996.

Cal/EPA, Report on AB 1890: Cost Shifting Strategies for the Benefits Attributable to the Solid Fuel Biomass Industry, on behalf of the State of California, April 1997.

Deb, R., Albert, R., and Hsue, L., Modeling Competitive Energy Market in California: Analysis of Restructuring, LCG Consulting report to the California Energy Commission, October 11, 1996.

Morris, G., The Environmental Costs and Benefits of Biomass Energy Use in California, NREL Report No. NREL/SR-430-22765, National Renewable Energy Laboratory, U.S. Department of Energy, May 1997.

Morris, G., Fuel Use and Other Characteristics of Biomass Power Plants in the U.S. and Canada, FRA report to Hydro Québec, December 1994.

March 1997. Final report issued: Policy Report on AB Renewable Funding, CEC Report to the Legislature. 
Table 1

Comprehensive Proposals to the CEC Renewables Program Committee

Renewables Industry Coalition

American Wind Energy Association

California Biomass Energy Alliance

Geothermal Energy Association

Solar Thermal Energy Association

Union of Concerned Scientists

Emerging Renewables Developers Proposals

PV4UConsortium

Solar Energy Industries Association

California Solar Energy Industries Association

Sacramento Municipal Utilities District

Green Energy Services Providers Proposal

Working Assets Inc.

Foresite Energy Inc.

Environmental Organizations Proposal

Environmental Defense Fund

Natural Resources Defense Council

Sierra Club

Landfill Gas Producers Proposals

Orange and Sonoma Counties

The City of Sacramento

NEO Corp. 


\section{Table 2}

Features of Proposals to the CEC Renewables Program Committee

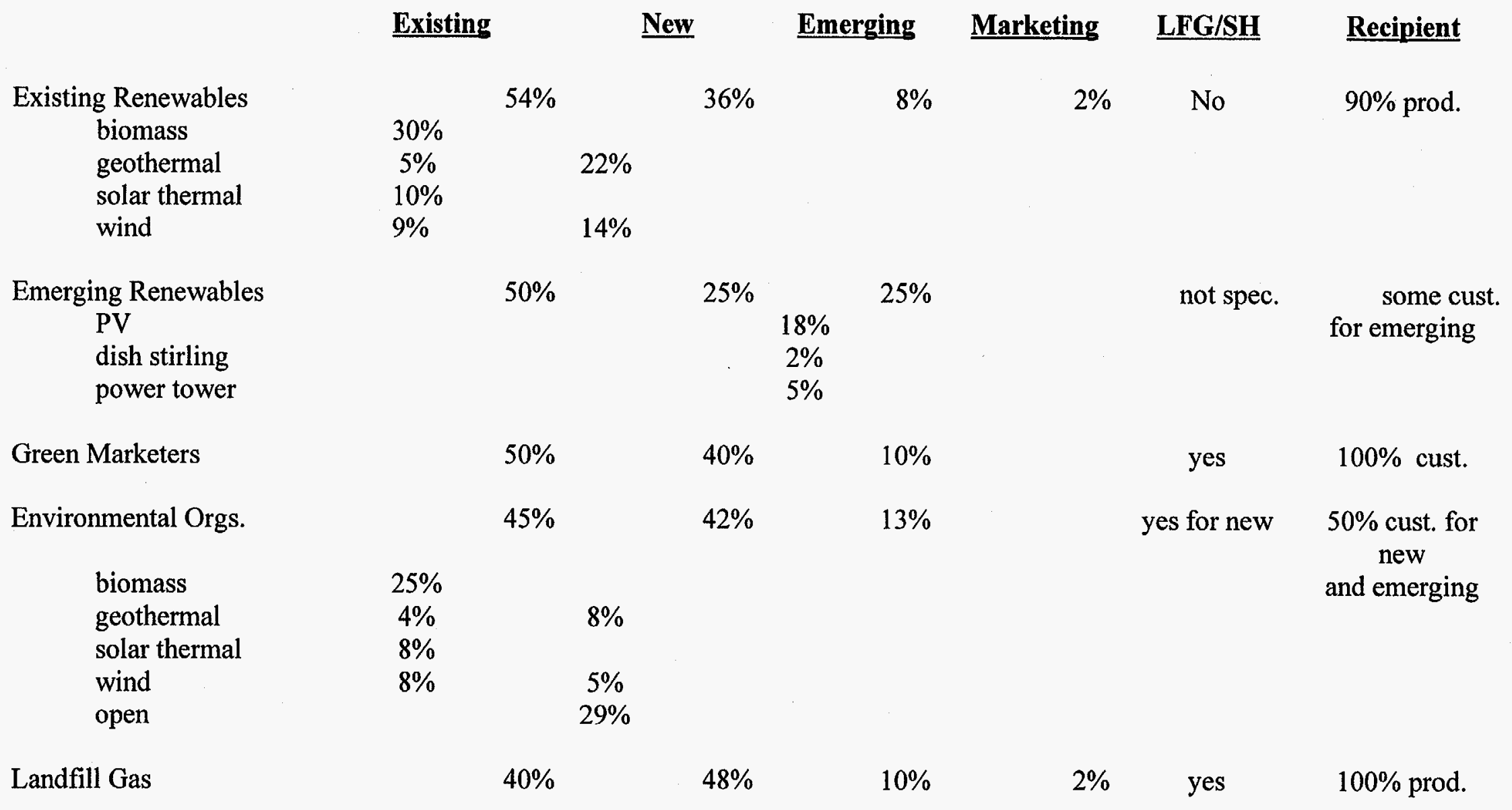


Table 3

\section{California Avoid Cost Rates}

Historical and LCG Projections

\section{PG\&E}

$\underline{\mathrm{SCE}}$

Actual Avoided Costs

1992

2.96

2.99

1993

2.82

3.20

1994

2.35

2.55

1995

1.85

2.09

1996

2.16

2.50

1997

2.89

3.28

LCG Projections

1998

2.86

2.98

2001

3.23

3.37

2006

3.99

4.09 
Table 4

California Time-Differentiated SRAC Rates, 1997

$\begin{array}{lll}\text { Summer } & \underline{\text { PG\&E }} & \underline{\mathrm{SCE}} \\ \text { Peak } & 2.76 & 4.68 \\ \text { Partial Peak } & 2.65 & 3.40 \\ \text { Off Peak } & 2.55 & 2.80 \\ \text { Super Off Peak } & 2.45 & \\ & & \\ \text { Winter } & & 4.00 \\ \quad \text { Partial Peak } & 3.29 & 3.06 \\ \text { Off Peak } & 3.16 & 2.55 \\ \quad \text { Super Off Peak } & 3.03 & \end{array}$


Table 5

\section{Characteristics of Biomass Fuels Used in California}

Wood

Processing

Residues

Current Cost $(\$ / b d t)$

Use during 1990s (mil.bdt)

Major Disposal Alternative

Potential for Expanded Use

Supply Curve Slope (\$/mil. bdt)
$12-25$

$1.3-2.8$

landfill

burial

limited

8

$\begin{gathered}\text { In-Forest } \\ \text { Residues }\end{gathered}$
$25-38$
$0.36-1.0$
in-forest
accumulation
great

23
Urban

Agricultural

$\underline{\text { Residues }}$

23-353

$0.74-1.2$

open

burning

great

21
Wood

$\underline{\text { Residues }}$

15-25

$0.80-1.4$

landfill

burial

moderate

18 
Table 6

Cost Shifting Needs for Biomass Power Production ( $/$ / kWh)

\begin{tabular}{|c|c|c|c|c|}
\hline & $\begin{array}{c}\text { Wood } \\
\text { Processing } \\
\text { Residues } \\
\end{array}$ & $\begin{array}{l}\text { In-Forest } \\
\text { Residues } \\
\end{array}$ & $\begin{array}{c}\text { Agricultural } \\
\text { Residues } \\
\end{array}$ & $\begin{array}{c}\text { Urban } \\
\text { Wood } \\
\text { Residues } \\
\end{array}$ \\
\hline \multicolumn{5}{|l|}{ Revenues } \\
\hline SRAC & 3.0 & 3.0 & 3.0 & 3.0 \\
\hline Capacity & 1.7 & 1.7 & 1.7 & 1.7 \\
\hline Total & 4.7 & 4.0 & 4.0 & 4.0 \\
\hline \multicolumn{5}{|l|}{ Costs } \\
\hline Capital (existing facility) & 2.1 & 2.1 & 2.1 & 2.1 \\
\hline Non-Fuel O\&M & 2.3 & 2.3 & 2.3 & 2.3 \\
\hline Fuel & 1.2 & 2.5 & 2.1 & 1.7 \\
\hline Total & 5.6 & 6.9 & 6.5 & 6.1 \\
\hline Net Cost-Shifting Need & 0.9 & 2.2 & 1.8 & 1.4 \\
\hline
\end{tabular}


Table 7

Average Cost of Biomass Fuel Production in California ( $\$$ / bdt)

\begin{tabular}{|c|c|c|c|c|}
\hline & $\begin{array}{c}\text { Wood } \\
\text { Processing } \\
\text { Residues }\end{array}$ & $\begin{array}{c}\text { In-Forest } \\
\text { Residues }\end{array}$ & $\begin{array}{c}\text { Agricultural } \\
\text { Residues }\end{array}$ & $\begin{array}{c}\text { Urban } \\
\text { Wood } \\
\text { Residues }\end{array}$ \\
\hline Commodity Cost & & & & 1.50 \\
Harvesting/Collection & 1.0 & 7.50 & 6.00 & 5.00 \\
Processing & 4.0 & 5.00 & 6.50 & 12.50 \\
\hline Transportation & & & & 10.00 \\
\hline Total & 7.5 & 15.00 & & 22.50 \\
\hline
\end{tabular}




\section{Table 8}

\section{Schedule of CIWMB Workshops Biomass Cost Shifting Strategies}

General / Introductory Workshop, Benefits Attributable to Biomass Power Production

$1 / 14 / 97$

Economics of Biomass Power Production

$1 / 17 / 97$

Cost-Shifting Strategies for Agricultural Residue Fuels

$1 / 21 / 97$ Cost-Shifting Strategies for In-Forest Residue Fuels

$1 / 23 / 97$ Cost-Shifting Strategies for Urban Waste Wood Fuels April 1997

Final report issued: Report on $A B 1890$ (Chapter 854, Statues of 1996), Cost Shifting Strategies for the Benefits Attributable to the Solid Fuel Biomass Industry 
Figure 1

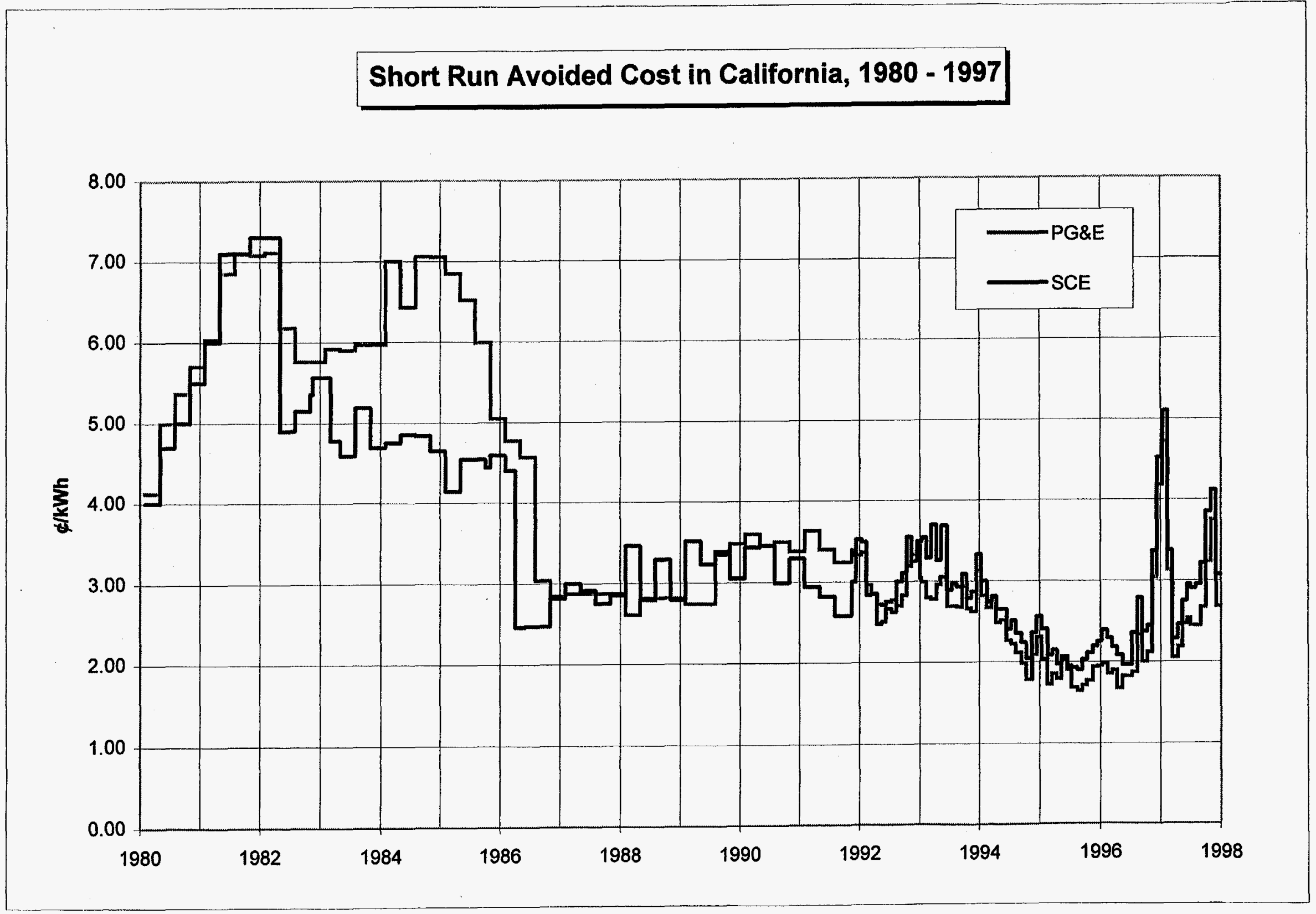


Figure 2

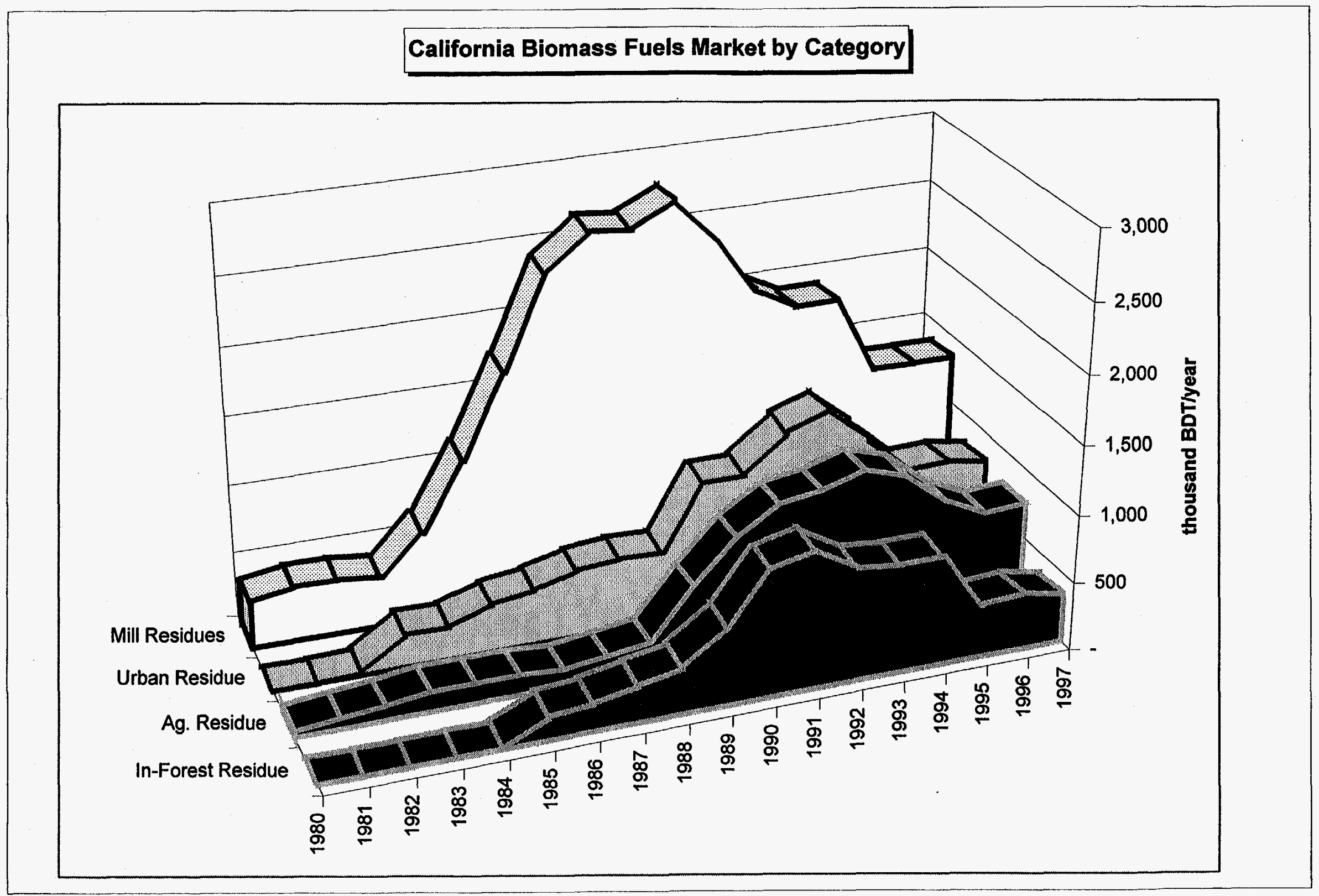




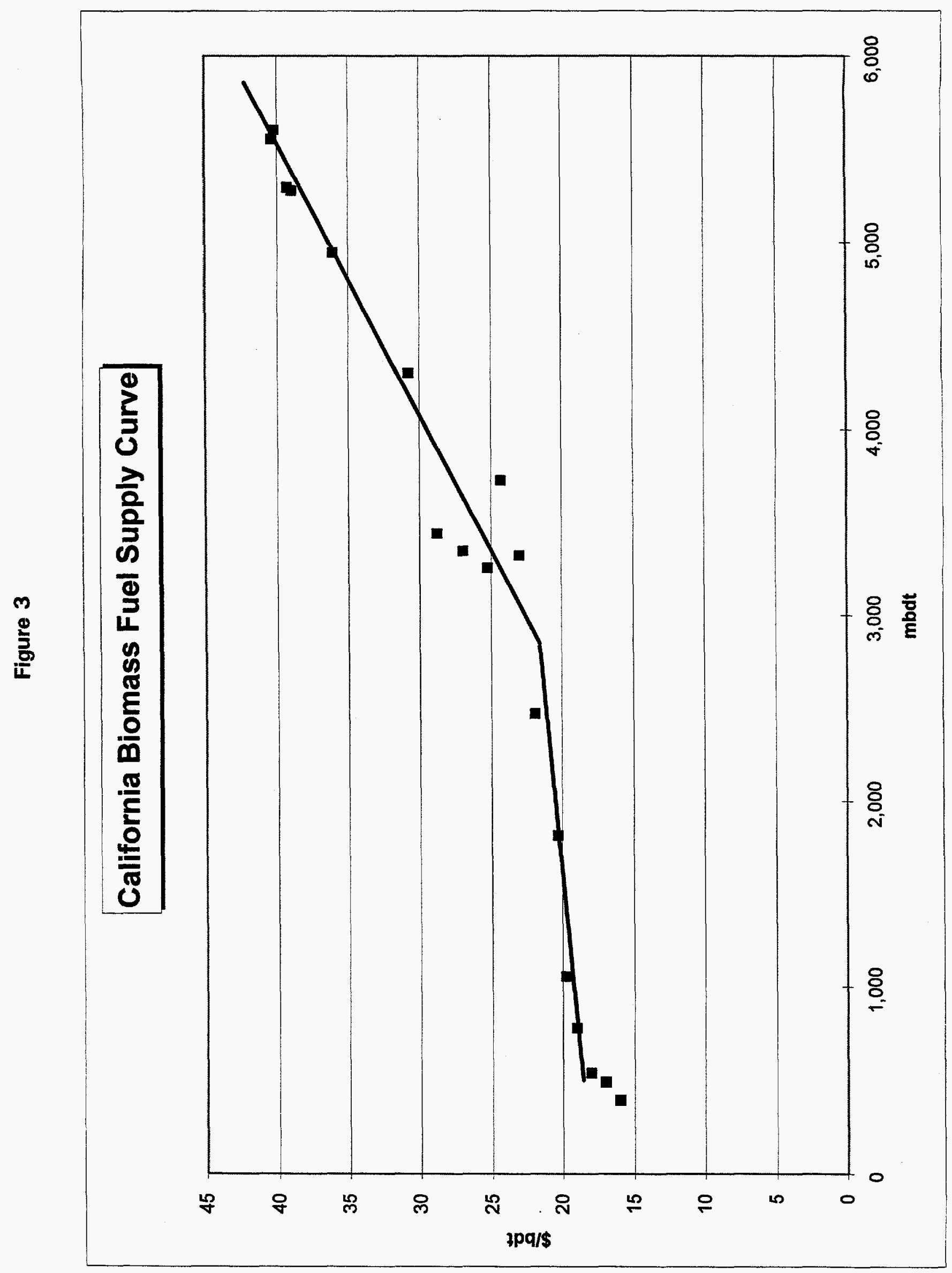




\section{Appendix 1: Full Text of AB 1890, Article 7, Section 383}

383. (a) Moneys collected pursuant to paragraph (3) of subdivision (b) of Section 381 shall be transferred to a subaccount of the Energy Resources Programs Account of the California Energy Resources Conservation and Development commission to be held until further action by the Legislature for purposes of:

(1) Supporting the operation of existing and the development of new and emerging in-state renewable resource technologies.

(2) Supporting the operations of existing renewable resource generation facilities which provide fire suppression benefits, reduce materials going into landfills, and mitigate the amount of open-field burning of agricultural wastes.

(3) Supporting the operations of existing, innovative solar thermal technologies that provide essential peak generation and related reliability benefits.

(b) The California Energy Resources Conservation and Development Commission shall review the purposes described in this section and report to the Legislature by March 31, 1997, with recommendations regarding market-based mechanisms to allocate available funds. The programs should be based on market principles and include options and implementation mechanisms which:

(1) Reward the most cost-effective generation mechanisms such as the establishment of a clearinghouse or a marketing agent to identify the most competitive renewable resource providers while fostering a market for renewable resources.

(2) Implement a process for certifying eligible renewable resource providers.

(3) Allow customers to receive a rebate from the fund through mechanisms such as a reduction in their electricity bill or a direct payment from the fund for the transition charges that would otherwise apply to their purchases from renewable resource providers.

(4) Allocate moneys between (A) new and emerging and (B) existing renewable resource technology providers, provided that no less than 40 percent of the funds shall be allocated to either category.

(5) Utilize financing and other mechanisms to maximize the effectiveness of available funds.

(c) The report described in this section shall also include consideration of:

(1) The need for mechanisms to ensure that cogeneration facilities that utilize energy from environmental pollution in its process, or microcogeneration facilities with a total generating capacity of less than one megawatt remain competitive in the electric services market.

(2) Whether fuel cells should be treated as fuel switching for purposes of application of the competition transition charge as specified in Section 371. 


\section{Appendix 2: $\quad$ Schedule of CEC Hearings and Workshops, Renewables Program Committee}

10/16/96 En Banc Hearing on Irrigation Districts, Renewables, and RD\&D

11/4-5/96 Initial workshop on renewables issues

11/12/96 Workshop on non-renewables issues to be included in CEC report to the legislature on renewables

11/19/96 Initial hearing on allocation proposals submitted to the Renewables Program Committee

11/26/96 Second hearing on allocation proposals submitted to the Renewables Program Committee

12/3/96 Final hearing on allocation proposals submitted to the Renewables Program Committee

1/16/97 Hearing to receive comments on initial staff draft of CEC report to the legislature on renewables

2/27/97 Hearing to receive comments on committee draft of CEC report to the legislature on renewables

3/20/97 Hearing to receive final comments and obtain Commission approval of CEC report to the legislature on renewables

March 1997 Final report issued: Policy Report on AB 1890 Renewables Funding, CEC Report to the Legislature 


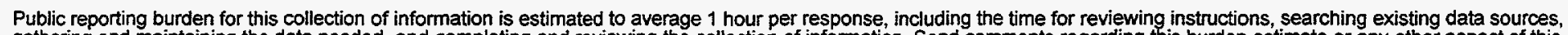

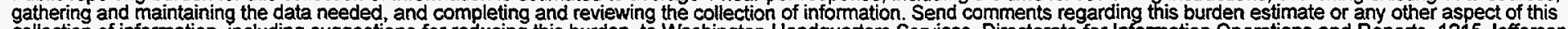

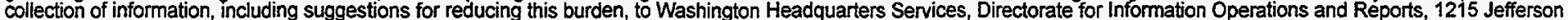

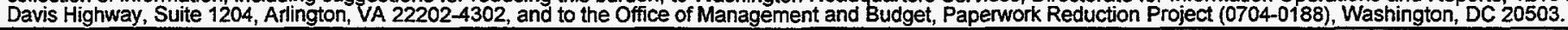
1. AGENCY USE ONLY (Leave blank)

\section{REPORT DATE}
3. REPORT TYPE AND DATES COVERED
July 1998
NREL Subcontract Report

\section{TITLE AND SUBTITLE}

The Implications of Deregulation for Biomass and Renewable Energy in California

\section{FUNDING NUMBERS}

Task \#: BP811010

6. AUTHOR(S)

Gregory Morris

7. PERFORMING ORGANIZATION NAME(S) AND ADDRESS(ES)

Future Resources Associates, Inc.

Berkeley, California

9. SPONSORING/MONITORING AGENCY NAME(S) AND ADDRESS(ES)

National Renewable Energy Laboratory

1617 Cole Boulevard

Golden, CO 80401-3393

8. PERFORMING ORGANIZATION REPORT NUMBER

10. SPONSORING/MONITORING AGENCY REPORT NUMBER

NRELSR-570-24851

\section{SUPPLEMENTARY NOTES}

\section{2a. DISTRIBUTION/AVAILABILITY STATEMENT}

National Technical Information Service

U.S. Department of Commerce

5285 Port Royal Road

Springfield, VA 22161 12b. DISTRIBUTION CODE

UC-600

13. ABSTRACT (Maximum 200 words) AB 1890 , California's landmark electric utility deregulation legislation, sets January 1,1998 as the date on which the electric utility industry would be deregulated. Electricity generation is the most capital-intensive industry in the economy, and presents a significant barrier to market entry.

\section{SUBJECT TERMS}

utility deregulation, $A B$ 1890, renewables technologies 41

16. PRICE CODE

\section{SECURITY CLASSIFICATION OF REPORT}

18. SECURITY CLASSIFICATION OF THIS PAGE
19. SECURITY CLASSIFICATION OF ABSTRACT
20. LIMITATION OF ABSTRACT

Standard Form 298 (Rev. 2-89) Prescribed by ANSI Std. 239-18 